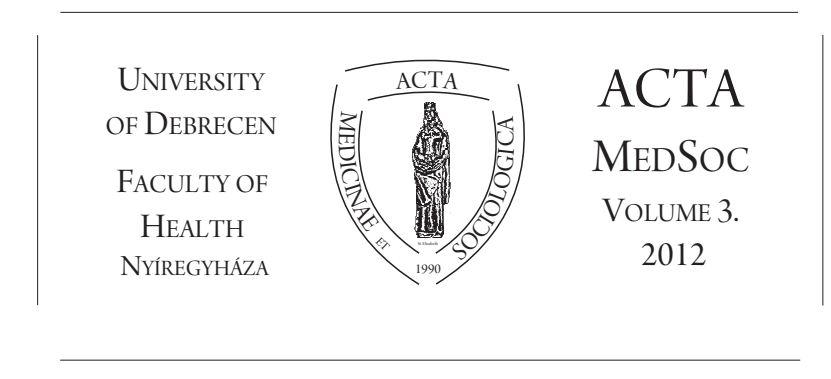

\title{
Adalékok az Egészségügyi Kar történetéhez
}

\section{Fábián Gergely}

\author{
Debreceni Egyetem Egészségügyi Kar \\ Alkalmazott Társadalomtudományi Tanszék \\ e-mail: fabian.gergely@foh.unideb.hu
}

DOI: $10.19055 / \mathrm{ams} .2012 .3 / 6-7 / 1$

\section{A kar megalakulása, létrehozói}

2010 ôszén ünnepelte alapításának húsz éves évfordulóját a Debreceni Egyetem Egészségügyi Kara, hiszen jogelőd intézménye, a Debreceni Orvostudományi Egyetem Egészségügyi Fơiskolája 1990 szeptemberében tárta ki kapuit az elsó évfolyamok elótt. Akkor két szakon, 60 hallgató kezdhette meg tanulmányait SzabolcsSzatmár-Bereg megye legfiatalabb felsőoktatási intézményében, mivel a többoldalú egyeztetéseket követően a fóiskola nyíregyházi székhellyel kezdte meg múködését. 2010 azonban nemcsak a kar születésnapját jelentette. Sajátságosan kettôs jubileumról volt szó, mivel az elsô tíz évet követôen 2000-ben létrejött az integrált Debreceni Egyetem, melynek a kar ma is szerves része.

Az alapítók egy köre bizonyosan 22 évesnek tartaná az intézményt, mivel a fôiskola létrehozásának terve már 1988 nyarán megszületett, igaz ekkor még csak elképzelések léteztek a „folyamat jelleggel” kiépítendő fơiskoláról és az is bizonytalan volt, milyen szakok indulhatnak majd.

A szervezőmunka egy időben, több szálon is elindult. A Szabolcs-Szatmár-Bereg megyei Tanács részéről Gyúró Imre, az akkori elnökhelyettes, a fôiskola egyik legfốbb patrónusa és Dr. Lukácskó Zsolt az intézmény késóbbi fóigazgatója kezdték meg a tárgyalásokat az illetékes minisztériummal, annak szakbizottságaival, illetve a DOTE vezetésével. Az ötlet gyakorlatilag mindenhol támogatókra talált, hiszen 1989. július 14-én már a megvalósítás konkrét lépéseiről egyeztettek Nyíregyházán az egyes szervezetek képviselôi. Az anyaegyetemet nemcsak Prof. Dr. Leövey 
András rektor képviselte, hanem az általa kinevezett rektori biztos, Prof. Dr. Karmazsin László, aki a késóbbiekben a Diplomás Ápoló szak egyik alapítója, illetve a védônóképzés felelős vezetője is lett. A megye vezetését továbbra is Gyúró Imre elnökhelyettes képviselte, aki nemcsak az alapításnál segítette az intézmény munkáját, hanem a következô évtizedekben is. Ôt a fôiskolán mindenki „Imre bácsiként” emlegette és emlegeti, ami jól jelképezi bensôséges viszonyát az intézménnyel és annak oktatói karával. Tizenöt évvel az intézmény megalapítását követően egy interjújában, már nyugdíjasként így emlékezett vissza az indulás időszakára:

„... egy kitünố szabolcsi, nyíregyházi csapat kellett ahhoz, hogy az álomból valóság váljon. Abban az idôben olyan nagytudású orvosai voltak a megyénknek, akik járták a világot, Európát, és nyitottak voltak az újra: amit külföldön tapasztaltak, szerették volna itthon is hasznositani. Ezen gondolatok egyike volt az, hogy a gyógyítás nem alapozhat kizárólag az orvosokra, feltétlenül szükség van egy olyan gárdára, amely - ha úgy tetszik, a második vonalban - kiszolgálja az orvosokat, lényeges és fontos résztvevóje a gyógyításnak. Az akkori orvoshiányban nagyon fontos volt ez a felismerés, amelynek külföldön már bevált gyakorlata volt ... Nagyon jó volt az együttmúködésünk Csehák Judit, akkori egészségügyi miniszterrel, jómagam pedig tagja voltam annak az országos reformelókészitoó bizottságnak, amely a népegészségüggyel foglalkozott.

A föiskola-alapítást ezen dolgok együttese tette lehetôvé. Úgy gondoltuk, itt az ideje annak, hogy föiskolai egészségügyi oktatás kezdödhessen a megyében. Annál is inkább, mert szerettük volna Szabolcs-Szatmár-Bereget ily módon is felemelni, sorsán javítani. Nem hallgathatom el, hogy az ötletnek bizony számos ellenzöje is akadt, de a helyi erók, no meg Csehák Judit és a Debreceni Orvosegyetem segítségével mégis sikerült a tervet megvalósítani."

Hasonló gondolatokat kiemelve nyilatkozott az alapításról Dr. Leövey András egyetemi tanár, a DOTE akkori rektora:

„A föiskola létesítése életem egyik legemlékezetesebb idôszaka volt. Három dolgot, három érdeket kellett egyszerre egyeztetni: az egyetem, a város, illetve a megye, valamint a minisztérium érdekeit. A nyíregyháziakat és minket legjobban két dolog izgatott: Kelet-Magyarországon úgy növelni az egészségügy színvonalát, hogy a gyógyításban magasan képzett emberek dolgozzanak, s hogy megteremtsük a szabolcsi fiatalok számára a lehetôséget a továbbtanulásra ... . Nekem a kezdetektól szívem csücske a föiskola ügye, hiszen nyíregyházi vagyok, itt születtem, ma is élnek ott rokonaim. Számomra a fóiskola létezése egyértelmüen bizonyítja, hogy a nagy dolgok az embereken múlnak: Lukácskó Zsolt és Karmazsin László lelkesedése, tudása nélkül ma nem tartanánk ott, ahol vagyunk. A kezdetekben tanítva tanultunk, hiszen az új dolgokat mindnyájunknak el kellett sajátítanunk.”

A tárgyalásokba ekkor már bekapcsolódott Nyíregyháza város vezetése is, pontosabban Csabai Lászlóné tanácselnök, illetve az akkori Népjóléti Minisztérium Szociális Szakképzési Bizottságának vezetôjeként Dr. Ferge Zsuzsa, mivel ekkor született döntés arról, hogy Magyarországon is elindul a szociális munkás képzés, a minisztérium pedig helyet keresett az új szak számára az ország több városában. 
Ennek a bizottságnak ragja volt Dr. Lukácskó Zsolt is.

A megállapodások szerint a gyakorlati képzés helyszínét a Jósa András Kórház és Rendelőintézet biztosította, így az alapítók között volt az intézmény akkori fóigazgatója, Dr. Vágvölgyi János is, illetve Dr. Szegedi János főorvos, aki késóbb a klinikai gyakorlatok igazgatója lett a karon.

A kezdetekre, az intézmény születésére, az alapítás körülményeire így emlékezett vissza Dr. Lukácskó Zsolt, aki nemcsak egyik alapítója volt a főiskolának, hanem 17 éven át irányította, formálta annak munkáját, fejlődését.

„Számomra a fennállás óta eltelt húsz esztendóbôl az elsố tíz év volt a legizgalmasabb, legemlékezetesebb, igy érthetô, ha erról az idôról mindig nagyon nagy örömmel beszélek. Ez ugyanis egy csodálatos része volt az életemnek, az az idôszak, amikor a szinte minden irányból érkezô jóindulat és a támogatás, a segítókészség volt érzékelhetô, amikor joggal érezhettem úgy, hogy belföldön és külföldön egyaránt értik a szándékainkat, s készek azt messzemenóen támogatni is. Vallásos emberként azt mondhatom, az intézmény csodálatos, felfelé iveló karrierje, a gyönyörü pálya, amelyen elindult - Isten áldását viselte, mondhatom úgy is, az Úr megáldotta a mi munkákat.

Miért fogalmazok igy? Azért, mert szeretném érzékeltetni, hogy gondok, nehézségek akkor is voltak, de volt jóakarat, és volt emberség is."

„Az egészségügyi föiskola létesitésével valamiben hittünk, valamiért felelósséget vállaltunk, amiból következik, hogy felelôsségeink vannak a jelenére, illetve a jövójére nézve is" mondta Dr. Szegedi János fôorvos, aki szerint az intézmény létrejötte valami olyasmi, mint a családalapítás: Dr. Lukácskó Zsolt és Gyúró Imre húsz évvel ezelőtt elhatározták, létrehoznak Nyíregyházán egy olyan egészségügyi képzést nyújtó iskolát, amely a gyógyításban nélkülözhetetlen felsófokú végzettséggel rendelkezô szakembereket képez.

Tették ezt azért, mert átlátták, hogy az egészségügyben nemcsak orvosokra, de jól képzett szakemberekre is szükség van.

„Jómagam orvosként rendkívüli módon örültem a kezdeményezésnek, és csatlakoztam hozzájuk. Nyugodtan mondhatom, megszállott csapat voltunk. Lelkesedésben, elszántságban nem volt hiány, miközben szinte családias volt a hangulat, kis túlzással úgy is fogalmazhatok: együtt tanult tanár és diák. Tény ugyanakkor, hogy két évtizede még igencsak orvoscentrikus volt a gyógyítás, a középkáderek szerepéról kevés szó esett. Ma már szerencsére más a helyzet. Meggyózódéssel vallom, a gyógyítás team munka, ahol az orvos mellett a diplomás ápoló, a mentótiszt vagy éppen az informatikus egyenrangú szereplönek számít. Azt szoktam mondani, hogy mindentudó orvos nincs, ma holisztikus gyógyítás zajlik, ahol nem egyes szerveket, de az egész embert gyógyítjuk, s ehhez megfeleló munkatársakra van szükség. Ebben a tekintetben pedig rendkivüli szükség van az egészségügyi föiskolára, a DEOEC Egészségügyi Karára, ahol éppen ezeket a munkatársakat képezik. Az intézmény fontossága és népszerüsége egyre nagyobb, ami érthetó, hiszen napjaink egészségügyében, a minôségbiztosítás korában lényeges szempont, hogy a gyógyításban kinek mi a kompetenciája, felelôssége, feladata. Amíg ez nem tisztázódott, addig azt sem 
lehetett pontosan megmondani, adott esetben hány kórházra, hány orvosra és nóvérre van szükség.

Az egészségügyi fóiskola alapításában dr. Lukácskó Zsolt érdemei elévülhetetlenek. Ó egy rendkivüli ember, aki az alapítók mellett méltó társakat kapott a késóbbiekben Dr. Muszbek László, Dr. Fésüs László, Dr. Paragh György személyében, de a névsor közel sem teljes."

A sikeres egyeztetéseket, valamint az MSZMP vagyonának elosztásáról hozott parlamenti döntést követően még az év végén, december 28-án átadásra került a fôiskola részére a párt Sóstói úti Oktatási Igazgatósága, azaz a korábbi pártfőiskola, vagy ahogyan azt a köznyelvben emlegették a "Fokszi-Makszi", ami egyszerre utalt egy akkoriban népszerû rajzfilmsorozat főszereplőjére, illetve az intézményben folytatott, marxista alapokon nyugvó politikai képzésre.

Valószínúleg ma már kevesen tudják, hogy az eredeti tervek szerint ezt az épületet az akkori Bessenyei György Tanárképző Főiskola kapta volna meg, hiszen Örökösföldön, a mai Zay Anna Gimnázium és Egészségügyi Szakközépiskola mögötti üres területen éppen az egészségügyi főiskola számára készült el egy oktatási épület, azzal a céllal, hogy a késóbbiekben integráltan múködjenek a középfokú és a felsófokú egészségügyi képzések. Az épület végül is más funkciót kapott, az akkori (ma már talán irigylésre méltó) demográfiai helyzetre való tekintettel hosszú ideig általános iskolaként múködött, jelenleg pedig a Westsik Vilmos Élelmiszeripari Szakközép-és Szakiskolának ad helyet.

Az épületet a fôiskola szerzôdésben foglaltak szerint ,ideiglenes jelleggel” három évre kölcsön adta a városnak a demográfiai gondok enyhítésére való tekintettel, azzal, hogy azt „eredeti állapotában helyreállítva” fogja visszakapni - ami nem történt meg. Csabai Lászlóné, Nyíregyháza akkori tanácselnöke, a késóbbiekben több cikluson át a város polgármestere egyik nyilatkozatában a következóképpen emlékezett vissza erre az időszakra:

„Máig nem felejtem a napot: Gyúró Imre és jómagam mentünk annak idején az egészségügyi fóiskola ügyében Csehák Judit miniszter asszonyhoz, aki méltányolta kérésünket, és minden tóle telhetố segítséget megadott. Így indultunk el, és többszörös ingatlancserék után, a pártvagyon felosztásának köszönhetöen, megszereztük a szükséges épületet, s adtuk továbbhasználatra a debreceni egyetemnek. Az orvosegyetem illetékesei a kezdetektôl kitünố partnereink voltak, mindenben támogattak bennünket."

A Sóstói úti épület átvételét nem sokkal megeloozve született meg az intézmény alapító okirata, amelyet az akkori jogszabályok értelmében, a még létezó ágazati irányításnak megfelelően, a múvelődési miniszterrel egyetértésben, a Szociális és Egészségügyi Minisztérium állított ki, Dr. Csehák Judit népjóléti miniszter aláírásával. Az okirat szerint a fóiskola 1990. szeptember 1-jei hatállyal került megalapításra, a Debreceni Orvostudományi Egyetemen, Nyíregyháza telephellyel.

Az alapító okiratban foglaltak szerint a megye és Nyíregyháza város közösen biztosította a főiskola múködésének épület-feltételeit, a DOTE garantálta a szakmai felügyeletet és az irányítást, a szakminisztérium pedig az oktatás költségeinek 
finanszírozását. Az intézmény megteremtésének egyértelmú céljai között az alábbiak szerepeltek:

- az egészségügy átalakításának igénye, a szükséges szakképzett munkaerô biztosítása,

- az elmaradottnak minősített régió felemelkedésének előmozdítása,

- a megyeszékhely felsőoktatási intézményi kínálatának bővítése,

- a munkanélküliség csökkentése,

- a szociális ellátás/gondoskodás színvonalának emelése.

Mindezen elôzményeket követően 1990. szeptember 1-jén került megrendezésre az első tanévnyitó ünnepség, amely egyben az első fơiskolai kari tanácsülés is volt. Az elsố tanítási nap szeptember 4-re esett, ekkor két szakon, a Védônô és az Általános Szociális Munkás képzésben indult meg az oktatás, 60 hallgatóval, 5 főállású oktatóval és 2 fố gazdasági-adminisztratív dolgozóval. Az elsô főiskolai tanács elnöke Dr. Lukácskó Zsolt volt, tagjai pedig Dr. Ráczné Dr. Kassy Erzsébet docens, Prof. Dr. Karmazsin László egyetemi tanár, Tatár Katalin szociális munkás hallgató, Mester Erika védőnő hallgató, Buczi Judit gazdasági előadó.

Az indulás idôszakát felelevenítve így írt errôl a későbbiekben Dr. Karmazsin László professzor, korábbi rektor, a főiskola „egyetemi mentora”:

„Máig emlékszem a napra: 1989. június 20-án keresett meg a DOTE akkori rektora, Leövey András barátom azzal, hogy megérkezett hozzá az alapító okirat, amely arról értesit, hogy Nyíregyházán védónô és szociális szak beinditásával fóiskolai oktatás kezdôdik ... Nagyon szívesen idézem vissza 1989 karácsonyát, amikor összeállt az a csapat, amelyet én azóta is aranycsapatnak nevezek. Ferge Zsuzsa, Gyúró Imre, Csabai Lászlóné, Leövey András, Lukácskó Zsolt, Hunyadi Károlyné Marika, Zagyi Bertalan. Ôk voltak azok, akik nélkül a nyíregyházi föiskola nem jött volna létre. S hogy miért tartom az intézmény megszületését rendkívül fontos sikernek?

Gyermekgyógyászként számomra a védônóképzés volt a legnagyobb öröm, hiszen meggyőzôdéssel vallottam, nélkülük nem létezhet gyermekgyógyászat, munkájuk és tudásuk nélkülözhetetlen. Azt, hogy képzésük föiskolai szinten történhet, különösen nagy sikernek éreztem, ezért is segítettem, tettem meg minden tólem telhetôt. Voltak persze könnyebb és nehezebb idöszakok. A kezdeti nehézségek után mindnyájunk számára megnyugvást jelentett, amikor eldôlt: az oktatás csakis az egyetem égisze alatt történhet, igazolva és garantálva ezzel a megfelelô magas színvonalat."

A kezdetekkor az intézmény sajátságos, ugyanakkor igen rugalmas struktúrát alakított ki. Nem léteztek még tanszékek, csak szakok, a szakok élén pedig ún. szakigazgatók álltak, akik feleloosek voltak a teljes képzési szerkezetért. Az induló képzések esetében Dr. Lukácskó Zsolt (Általános Szociális Munkás szak) és Dr. Orosz-Tóth Miklós (Védônô szak) voltak a vezetôk, akik nemcsak a szakokat irányították, hanem adott időszakokban a fooiskola fóigazgatói posztját is betöltötték. 
A főiskola létrejötte széleskörú összefogás eredménye volt, ahogyan Dr. Gergely Lajos, a DOTE késóbbi rektora egyik nyilatkozatában fogalmazott: „Optimális modellje egy olyan intézmény születésének, amelyet egységes társadalmi igény és a szükséglet harmonikus együtthatása hívott létre".

Az elsô tanévben indított szakok esetében a védônôk képzésének már megvoltak a hazai elôzményei, a szociális munkás képzés azonban unikumnak számított, hiszen Magyarországon egy teljesen új szakról volt szó. Mivel az Egyesült Államokban és Nyugat-Európában a képzésnek már több évtizedes hagyományai voltak, nem véletlen, hogy a tanterv kidolgozásánál a nemzetközi minták domináltak, illetve különbözô ösztöndíjakkal számos külföldi szakértô segítette a képzés kialakítását. Nyíregyházán a Fulbright ösztöndíjas Dr. Richard Steinmann dolgozott hónapokon át, segítve a helyi tanterv kialakítását, illetve a 4 éves fôiskolai képzés szerkezetének, gyakorlatának kidolgozását. Természetesen az sem volt véletlen, hogy a minisztériumi döntés alapján hazánkban sok helyen az egészségügyi fơiskolákhoz kapcsolódóan indult el a képzés, illetve, hogy régiónkban, Szabolcs-Szatmár-Bereg megye közismert szociális helyzetét figyelembe véve nyíregyházi helyszínnel alapították meg a szakot. Az indulás egy szempontból nem volt teljesen zökkenômentes, hiszen a képzés elnevezése (az amerikai social work, illetve a német Sozialarbeit elnevezések tükörfordítása) különösen a rendszerváltás időszakában sokak számára volt zavaró. A közvélemény nem értette, miért képeznek egy főiskolán „szocialista munkásokat", az egyetemek vezetői pedig szintén nehezen emésztették meg, hogyan kerül egy „munkásképzés” a felsőoktatásba. Az egyik alapító, Dr. Horváth László, aki a késóbbiekben a szak helyettes vezetője is volt, így emlékszik vissza erre az idôszakra:

„Sose felejtem el, ahogyan dr. Lukácskó Zsolt a közös munkára invitált. Azt mondta: a terven kívül még semmi nincs meg, de van egy jó ötlet. Ha elhiszed, hogy ebból a tervból, ebból az ötletból lesz is valami, csatlakozz hozzám! Elhittem, és ezt azóta egyetlen percre sem bántam meg. Bô fél évem úgy telt el, hogy mindenféle hivatalos munkaviszony nélkül, mondhatni kedvtelésból, kiváncsiságból, a szabadságom terhére végeztem itt a munkát.

Akkoriban, 1989-ben ugyanis a magyarországi szociális képzésnek nemhogy nyíregyházi, de országos programja sem volt! Az én kötódésem és feladatom volt, hogy épitsünk egy fóiskolát, ahol szociális munkásokat képezhetünk. 1990 februárjában, Sopronban egy országos konferencián azok gyúltek össze, akik akkoriban hazánkban a szociális képzés körül bábáskodtak. Az elsố nyilvános megjelenésünket ez a tanácskozás jelentette.

Külön öröm, hogy ezen a konferencián mi már komplett testülettel tudtunk megjelenni, elmondhattuk ötleteinket, azt hiszem, itt kovácsolódtunk igazi tantestületté is. Ezen a tanácskozáson dólt el az is, mit fogunk tanítani, milyen tanterv szerint történik majd az oktatás. Itt szereztük meg Richard Steinmann barátságát, akinek sok szakmai segítséget köszönhetünk. Sopronból tehát már úgy jöttünk haza, hogy van országos programunk, de Nyíregyházán sem helyünk, sem pedig hallgatóink nem voltak. 
Ezért aztán szorgos toborzásba kezdtünk, miközben megalkottuk a helyi tantervet is. Ebben egyszerübb volt az elméleti tantárgyakat elhelyezni, hiszen az országos program, illetve a helybéli, jó nevú szakemberek sokat segitettek. A gyakorlati tantárgyaknál azt vettük észre, hogy az elméletnél jóval bonyolultabb dolog, hiszen szinte maga a fogalom is ismeretlen volt. A gyakorlóhelyek szervezésébe kezdtünk, s legnagyobb örömünkre óriási érdeklödést, nyitottságot tapasztaltunk.

A szociális intézmények, idôsek otthonai, gondozó és családsegítö központok az elsố szóra jöttek, segítettek, amit tudtak. Mindenki tudni akarta, mi a képzés lényege, jövóbeni haszna. Ennek a lelkesedésnek, összefogásnak köszönhetöen szeptemberre már volt épületünk, tantermeink, hallgatóink is. Nyugodtan kijelenthetó, egy év alatt a semmiból új szakot építhettünk Nyíregyházán. Az elsố végzett hallgatóink 1994-ben vehették kézbe a diplomát. Minden hallgató álláslehetóséget kapott, ez pedig egyértelmúen bizonyította: müködik a program, szükség van ránk."

A „Soproni konferencián” a Nyíregyházára tervezett képzést Dr. Lukácskó Zsolt, Dr. Horváth László, Dr. Bugán Antal, Erdős Judit, Kerülő Judit és Pataki János képviselte. Dr. Ferge Zsuzsa, egyetemi tanár, akadémikus, a szociális képzések megalapításának egyik legfóbb szorgalmazója és alapítója egyik visszaemlékezésében a következố gondolatokkal elevenítette fel nyíregyházi élményeit:

„Az iskolát hamarabb ismertem meg, mint ahogy formailag létrejött ... A nyolcvanas évek közepén sokunk összefogásával elindult egy mozgalomféle a szociális munkás képzés megteremtéséért. Külföldre jártunk a szakma tanítását megtanulni ... s mindebben valahogy partnerré vált az akkori kormányzat két vezetôje, Csehák Judit és Bánfalvi István. Egymás után jelentkeztek pesti és vidéki egyetemek és fóiskolák, hogy bekapcsolódjanak a képzés egységes kereteinek kidolgozásába, hogy végül hivatalosan létrejöhessenek az új szakok.

A nyíregyházi kollégák egyike volt az elsóknek, akik tudták, hogy errefelé akarnak elindulni ... Az iskola néhány mai tanárát a nyolcvanas évek végén hallgatóként ismertem meg, Lukácskó Zsoltot nem sokkal késóbb. Ámulattal figyeltem azt a kreativitást, ahogy minden hazai és külföldi lehetôséget, anyagi és szellemi eröforrást felhasználtak, hogy felépítsék az ország szellemileg egyik legnyitottabb, technikailag biztos a legjobban felszerelt, értöen müködtetett intézményét ... Egyébként ahányszor beszélgettünk elóadások közben vagy után, mindig megkapott a hallgatók és tanárok nyitottsága, a környezet problémái iránti érzékenység."

A Védőnő Szak indulását és későbbi fejlődését a következóképpen elevenítette fel Lampé László professzor, aki Dr. Orosz Tóth Miklóst követve volt hosszú ideig a szak vezetóje:

„Jómagam a védônóképzés felelôse voltam, Hajdú és Szabolcs megyéból fogadtuk a hallgatók többségét. A védônóképzéshez egyetemi háttérre van szükség, ezt a debreceni orvosegyetem vállalta magára. Jól emlékeztünk ugyanis még arra, amikor Miskolcon megszüntették a védőnóképzést, minek következtében drámai helyzet állt elö ezen a területen.

A nyíregyházi föiskola a helyiek, a város és a megye, valamint az Egészségügyi Minisztérium összefogásával valósulhatott meg. Létét nemcsak a múlt, a jelen 
igénye is igazolja ... Számomra a védônóképzés rendkíül fontos terület, hiszen nemcsak a múltban, de a jövóben is nagy szükség van rájuk. A védônói szolgálat Magyarországon csodálatosan szervezett és hosszú évek óta eredményes, sikeres. A védőnönek a gyermek születése utáni 24 órán belül ott kell lennie az anyánál, akit praktikus, hasznos tanácsokkal lát el. Éppen azért a képzés fenntartását és fejlesztését kivánatosnak és fontosnak tartom, s ebben a nyíregyházi fóiskola rendkívül sokat segitett, komoly szerepet vállalt."

Lampé professzor visszaemlékezésében arra is meggyőzően utalt, miért éppen nyíregyházi helyszínnel kellett a főiskolát létrehozni: „Nem titok az sem, hogy a fövárosban, vagy éppen a Dunántúlon végzettek nem jönnek erre dolgozni, a szakemberhiányt enyhíteni. Márpedig ha javitani akartunk a helyzeten, az oktatást kellett közelebb hoznunk".

A képzés múködtetésében a felelős vezetők számára jelentős segítséget nyújtott a szak igazgatóhelyettese Dr. Vágvölgyi Jánosné.

Az indulás után már az elsố tanév során kialakultak azok az elképzelések, hogyan, milyen ütemezéssel és mely képzések kerüljenek engedélyeztetésre a képzési kínálat bóvítésére. A terveket kifejezetten gyors ütemben sikerült megvalósítani, hiszen 1991 szeptemberében már egy új szak fogadhatott hallgatókat.

Ez volt a hazánkban akkor még szintén ismeretlen és új képzésnek számító Egészségügyi Ügyvitelszervező Szak, amely alapvetően az egyre rohamosabban fejlődő egészségügyi informatika ismereteire képezte a hallgatókat.

Dr. Lukácskó Zsolt, Dr. Lehotszky Pál minisztériumi fôosztályvezetô nyíregyházi látogatásán vetette fel elôször az egészségügyben is egyre inkább tért hódító informatika-oktatás szükségességét. Elképzelését egyeztette Richard Steinman professzorral, aki segítséget ígért az ötlet kedvezô szakminisztériumi fogadtatása esetén. Ezután kereste fel Dr. Jávor Andrást a Népjóléti Minisztérium Reformtitkárságának vezetôjét, akivel megállapodtak a fôiskola profilját bôvítô, Magyarországon eddig nem oktatott új szak munkáinak megkezdéséról.

Richard Steinman professzor a chicagoi kollégák segítségével igen rövid idő alatt átadta a szak tantervi alapjait képezó chicagoi curriculumot. A szak indításának szervezésében kimagasló érdemeket szerzett C. Dixon Benjamin professzor asszony is. Erre a curriculumra építve készült el a tanterv a legkiválóbb hazai szakértők együttmúködésében. Közülük, a már elhunyt Dr. Bordás István nevét ma egy számítástechnikai szaktanterem ôrzi a karon.

A szak alapító vezetői Dr. Szegedi János fơorvos és Dr. Zagyi Bertalan voltak, aki így emlékszik vissza a kezdeti időszakra:

„Az én történetem párhuzamos az intézmény történetével. Máig nem felejtem, amikor 1989. december 23-án azt a felkérést kaptam a DOTE akkori rektorától, hogy vállaljam el az intézmény múszaki feladatainak végzését, irányítását, múködjek közre az infrastrukturális feltételek megteremtésében, a müszaki, technikai feladatok ellátásában. Igent mondtam, s azóta itt vagyok. Az elsó két-három évben fóleg a gazdasági jellegú feladatok kötötték le az energiámat, de ahogyan a tennivalók sokasodtak, döntenem kellett. Az oktatást választottam, gazdasági ügyekkel csak mint 
vezető foglalkoztam.

Azt sem felejtem, milyen nehezek voltak az elsố évek. Nem mindenki örült ugyanis a föiskola-létesités ötletének, szerencsére azonban azok voltak többen, akik nemcsak útjára indították, de felkarolták, támogatták a kezdeményezést. Ez kifejeződött abban is, hogy viszonylag rövid idő alatt sikerült kidolgozni egy olyan képzési struktúrát, amely valós társadalmi igényekre épült, olyan diplomás hallgatókat bocsájtott ki, akiknek ezután nem volt nehéz az elhelyezkedés. A folyamatban természetesen megvolt az újdonság varázsa is".

Az egészségügyi ügyvitelszervező képzés esetében az újdonság varázsa nemcsak hazánkra volt igaz, hanem egész Kelet-Európára, hiszen hasonló képzés nem létezett ekkoriban a rendszerváltó országokban.

„Az indulásnál például jelentôs írásos és személyes segítséget kaptunk egy amerikai egyetemtöl, a szak tantervének összeállitásához pedig az ország legjobb tíz, profi szakemberét sikerült megnyernünk, a gyakorlati megvalósitás a Jósa András kórház, különösen dr. Szegedi János osztályvezetô föorvos nélkül pedig elképzelhetetlen lett volna. Induláskor az oktatói gárda kétharmada rendelkezett tudományos fokozattal.

A segítségnyújtásra további példa a szegedi és veszprémi egyetem oktatóinak, a GYÓGYINFOK igazgatójának támogatása, akik személyesen jártak át hozzánk azért, hogy ez a szak is sikeres lehessen! Büszkeséggel tölt el, hogy azok, akik az indulásnál jelen voltak, ma is bábáskodnak fölöttünk, figyelemmel kisérik tevékenységünket. Ma már nyugodt szívvel kijelenthetem, jól éreztünk rá az indulásnál arra, hogy a munkaeröpiac igényeit kell elsôsorban kielégítenünk, s az volt a mércénk, hogy az általunk kibocsájtott diplomákhoz mit szól a munkáltató, mit szól a piac."

A szociális munkás képzéshez hasonlóan az egészségügyi ügyvitelszervezô elnevezés hallatán is zavarba jöttek az emberek, nagy tanácstalansággal gondoltak arra, hogy vajon mire is képeznek ezen a szakon. Az ügyvitelszervezô név azonban már utal arra, hogy a szúkebb értelemben vett egészségügyi informatikánál szélesebb körú képzésrôl van szó, olyan szakemberekről, akik egyszerre jártasak az egészségügy, a finanszírozás, a közgazdaságtan, a menedzsment, az orvostudomány rendszerében, az informatikában és a számítástechnikában. Ez a képzettség természetesen azt is jelenti, hogy a végzettek ismerik az alapvető közgazdasági összefüggéseket, rendelkeznek egészségügyi gazdasági, vállalkozási, pénzügyi és számviteli ismeretekkel, ismerik a társadalombiztosítás, a betegbiztosítás rendszerét, a finanszírozási módokat, ennek kódrendszerét, az ehhez kapcsolódó adatszolgáltatási kötelezettségeket. Ez az interdiszciplináris szemlélet természetesen azt is jelentette, hogy a szakon folyó oktatáshoz informatikusokra, matematikusokra, orvosokra, közgazdászokra és mérnökökre egyaránt szükség volt.

1993 és 1999 között négy újabb képzést indított az intézmény. 1993-ban a Diplomás Ápoló Szak (alapító vezetôi Prof. Dr. Karmazsin László és Dr. Kovács Árpád), 1997-ben az Orvosdiagnosztikai Laboratóriumi Analitikus szak (Prof. Dr. Muszbek László akadémikus vezetésével), 1998-ban a Mentôtiszt képzés (Dr. Szép Imre irányításával), 1999-ben pedig a Gyógytornász képzés (Prof. Dr. Szepesi Kálmán és Dr. Gomez Roberto vezetésével) fogadhatott hallgatókat. 
1993 sok szempontból döntő év volt a kar történetében. Ez az év a védőnóképzés életében is jelentôs változást hozott, hiszen ekkor vált négy éves főiskolai képzéssé, a korábbi három éves rendszer helyett, illetve ekkor indult el több intézményben a Diplomás Ápoló szak, szintén nemzetközi minták alapján. A magyarországi képzés tantervének kidolgozásában, az ún. Project HOPE program keretén belül, elsôdlegesen Dr. Doris M. Modly, a Clevelandi Egyetem professzora segédkezett, aki szakmai konzultációk alkalmával többször járt Nyíregyházán is, sôt részt vett az első végzős évfolyam államvizsgáján is.

1993 szeptemberét megelőzően csak Budapesten volt főiskolai képzés diplomás ápoló szakon.

1993-ban egyidejúleg indult meg az oktatás a Pécsi, a Szegedi és a Debreceni Orvostudományi Egyetemen.

A képzés tíz éves jubileuma alkalmából Dr. Kovács Árpád így emlékezett vissza a szak megalapításának idószakára:

„Az Egészségügyi Fóiskolához való kötôdésem az 1980-as évek végén kezdôdött. Ekkor, mint a Megyei Kórház föigazgató-helyettese feladatul kaptam, hogy nyújtsak segítséget a föiskola megindulásához, a leendő orvos-oktatók és kórházi gyakorlati helyek kiválasztásához. Dr. Karmazsin László professzor úr, egykori tanárom színes egyénisége és elkötelezettsége a föiskoláért annyira magával ragadott, hogy alapvetốn befolyásolta sorsom további alakulását. Az 1992-es esztendô fordulatot hozott életemben. A Jósa András Megyei Kórházi pályafutásomat a DOTE Egészségügyi Fôiskoláján folytattam ... A feladat, a már müködô föiskolán megszervezni és elindítani a diplomás ápolóképzést. Ez az új típusú szakemberképzés még nem volt sehol az országban, sem curriculum, sem oktatási program, sem oktató".

A program kidolgozása 1992. ôszén kezdődött, a Népjóléti Minisztérium koordinálásával és felügyeletével, ahol a munka „vezéregyénisége” Sövényi Ferencné országos fônôvér volt. A curriculum kidolgozásában a legfóbb partner a Pécsi Orvostudományi Egyetem volt.

A diplomás ápoló szak esetében ráadásul egy olyan programot kellett kidolgozni, amely nemcsak az általános nemzetközi feltételrendszernek felel meg, hanem az Európai Tanács által elfogadott „Európai Egyezmény a nóvérek képzésérôl és oktatásáról" irányelveinek is, hiszen ez volt a feltétele a nemzetközi értékú diplomának.

A világ fejlett egészségkultúrájú országaiban ugyanis már 20-25 évvel korábban kidolgozták az ápolás, mint tudomány és hivatás elméleti alapjait, filozófiáját, kompetenciáit, és az oktatást is ezekre az alapokra helyezték, ráadásul nemcsak fôiskolai, hanem egyetemi diplomát adó képzés formájában is. A hazai ápolás minôsége nem felelt meg a nemzetközi követelményeknek, mivel az ápolás folyamata uniformizálódott, vertikális tagozódása megszűnt, az egészségügy segédmunkájává degradálódott, következésképpen presztízsét is elveszítette.

Ahogyan visszaemlékezésében Dr. Kovács Árpád is utalt: a hazai egészségtudományi képzéseket az „erôs kórházcentrikusság, a betegségek gyógyításának oktatása jellemezte. Nem kapott elég hangsúlyt az egészség, mint érték, az egészségfejlesztés, 
az egészség és szociális helyzet kölcsönhatásainak ismeretrendszere, ezek felismerése, kezelése. Nem épült be az etika, az önismeret, a kommunikációs készségfejlesztés. Pedig az ápolói hivatás tartalmában és módszereiben jól elkülönithetố ismeretrendszert képez, a fejlett országokban saját jogú hivatás, önálló diszciplína, amely egyenrangúan illeszkedik más hivatásokhoz, igy az orvosi hivatáshoz is".

Mindez azt is jelentette, hogy az ápoló képzést egy hazánkban teljesen újnak számító filozófia alapján kellett elindítani, azaz olyan szakembert kellett „kitermelni”, aki magabiztos, szakmailag felkészült, kreatívan gondolkodó, önálló munkára képes egészségügyi szakdolgozó. A DOTE segítő szándéka ebben az esetben sem hiányzott, hiszen olyan neves professzorok fémjelezték az oktatást, mint Dr. Boján Ferenc, Dr. Hadházy Csaba, Dr. Kövér András, Dr. Bíró Zsigmond, illetve Dr. Jóna István.

A képzés 1993-ban, több oktatáspolitikai döntést követően, két helyszínen indult el. A kelet-magyarországi régióban is meglévô hiányt pótló szak nappali tagozata Gyula város önkormányzata hosszú ideje megfogalmazott törekvéseinek megfelelően - a DOTE rektorának döntése alapján Gyulán, míg a levelezô tagozat Nyíregyházán kezdte meg múködését.

A nappali tagozat Gyulára kerülésével kapcsolatos rektori döntésben elsődlegesen az játszott szerepet, hogy a városban évtizedek óta folyt magas szintú ápolóképzés, valamint rendelkezésre álltak a tárgyi és személyi feltételek is. Az épületet a város biztosította, a gyakorlati oktatás színteréül pedig az elismert, akkor még 1400 ágyas Pándy Kálmán Megyei Kórház szolgált. A szak gyulai tagozatának első vezetője Dr. Dankó Miklós volt, a nyíregyházi levelezô képzést pedig Dr. Szabó Tünde irányította.

Az 1997-ben indított Orvosdiagnosztikai Laboratóriumi Analitikus szak szintén újdonság volt hazánkban. A tervezési folyamat már 1994-ben elindult, Prof. Dr. Muszbek László akadémikus és Dr. Góth László irányításával. A szakalapítási kérelmet a négy hazai orvostudományi egyetem (DOTE, POTE, SZOTE, HIETE) közösen készítette el, 1995 és 1996 folyamán zajlott le az engedélyeztetési folyamat, a képzés pedig 1997 szeptemberében indulhatott, nappali és levelezô formában. A laboratóriumi diagnosztika ekkor már az orvostudomány egyik leggyorsabban fejlődő területének számított, ahol a tudományos eredmények gyakorlati felhasználása, illetve a korábban csak tudományos kutatásban használt módszerek, múszerek rutin diagnosztikai alkalmazása a legrövidebb átfutási idővel történik meg. Ez a felgyorsult fejlődés tette szükségessé a diplomás szakemberek képzését Magyarországon is. Mivel a szak fóbb képzési moduljai a klinikai kémia, a mikrobiológia és a hisztokémia, illetve a képzés rendkívül gyakorlatorientált, szükségessé vált az oktatói kör bôvítése, így az oktatást a Debreceni Orvostudományi Egyetem és a Kossuth Lajos Tudományegyetem Kémiai Tanszékcsoportja közösen végezte, a két egyetem között létrejött együttmúködési szerzôdés alapján. A szak a kezdetektől debreceni székhellyel múködött.

Az orvosdiagnosztikai laboratóriumi analitikus szak célja olyan elméleti és gyakorlati felkészültséggel rendelkező felsőfokú végzettségú szakemberek képzése, akik 
képesek a klinikai és patológiai laboratóriumok analitikai munkájának önálló végzésére, a laboratóriumi munka szervezésére, kislaboratóriumok, illetve részlegek analitikai munkájának irányítására és jártasak a laboratóriumi adatfeldolgozás korszerú módszereiben, valamint a gazdálkodás kérdéseiben is.

A szak képzési programja a hazánkban tapasztalható hiányosságok megszüntetését, a laboratóriumi analitikai munkát végzố szakemberképzés színvonalának európai szintre történő emelését tûzte ki célul. A program nemzetközi tapasztalatokon és gyakorlaton és az ilyen képzettségú szakemberek iránti igény felmérésén alapult. A képzés szakmai követelményeinek, személyi és tárgyi feltételeinek csak az orvostudományi egyetemek bázisán múködő egészségügyi főiskolák tudtak eleget tenni.

A szak alapításának ötlete, a tantervi program kidolgozása, elfogadtatása Dr. Muszbek László akadémikus, egyetemi tanár érdeme volt. Munkatársaival korszerú, nemzetközi szintű képzés alapjait teremtette meg. A gyakorlati megvalósítást, a múködtetést Dr. Góth László fôiskolai tanár, a szakhoz szervesen illeszkedô postsecondary program kidolgozását Dr. Hársfalvi Jolán egyetemi docens segítette.

Úttörố vállalkozás volt a Mentootiszt szak bevezetése és indítása is, hiszen hazánkban, 1998-ban, elsôsorban Dr. Lukácskó Zsolt fóigazgató kezdeményezésére nyíregyházi székhellyel indult el az elsố nappali tagozatos képzés. A szak programjának kidolgozásában az egyetem részéről Prof. Dr. Udvardy Miklós rektorhelyettes, a gyakorlat oldaláról pedig Dr. Szép Imre, az OMSZ Hajdú-Bihar Megyei Szervezetének, Dr. Halmay Balázs, az OMSZ Szabolcs-Szatmár-Bereg Megyei Szervezetének vezetô foórvosai, Dr. Pikó Károly, a Jósa András Megyei KórházRendelôintézet Sürgôsségi Betegellátó Osztályának vezetô fooorvosa, valamint Ujvárosy András vezető mentôtiszt, a kar részérôl pedig Dr. Lipóczki Imre vettek részt. Dr. Lipóczki Imre az akkreditációs anyag elkészítésében, a tanterv elókészítésében oroszlánrészt vállalt Dr. Lukácskó Zsolt mellett, majd hosszú időn keresztül volt a szak igazgató helyettese is. A szak elsô igazgatója Dr. Szép Imre volt.

A képzés célja nemcsak a szakemberhiány pótlása volt, hanem a szakma segítése annak, az akkoriban kidolgozott, követelménynek a megvalósításában, amely szerint a bajba jutott emberhez 15 percen belül meg kell érkeznie a megfelelő szintû ellátásnak, esélyegyenlőséget teremtve ezzel az ország egész területén. Ez azt jelentette, hogy több esetkocsi szolgálatot újjá kellett szervezni, további mentőállomásokat kellett létrehozni, és szükségessé vált olyan szakemberek képzése is, akik a sürgôsségi betegellátás körülményei között szükségessé váló egyes orvosi beavatkozások szakszerú és biztonságos elvégzésére is alkalmasak. Ekkoriban indult el az a program is, mely egyes kórházakban, intézményekben a sürgôsségi betegellátó osztályok megszervezését tûzte ki célul, s amelyek szintén igényelték a jól képzett szakembereket, részben a már ekkor problémaként jelentkezô orvoshiány miatt is.

Dr. Balázs György professzor, aki Szép föorvost követően három évig, nyugdíjazásáig irányította a szak munkáját, egyik írásában így fogalmazott a mentótiszt képzés fontosságát illetôen:

„A mentôtiszti szak fontosságát nem kell különösebben hangsúlyozni, hiszen ók 
azok, akik az úgynevezett elsô ellátást végzik, megadják a betegnek a legfontosabb esélyt arra, hogy életben maradjon, maradéktalanul meggyógyuljon. Ehhez pedig arra van szükség, hogy a riasztástól számított tizenöt percen belül a mentôtiszt a helyszinre érjen, felismerje a bajt, és megtegye a szükséges lépéseket. Ha jól dolgozik, az orvosnak és páciensnek egyaránt nyert ügye, az élethez jó esélye van. Szakemberek elótt nem titok, hogy ez a tizenöt perces elérés ma még nem általános. Éppen a föiskolai képzés segithet azonban sokat abban, hogy a helyzet folyamatosan javul...A nyíregyházi föiskolán hetvenéves koromig dolgoztam, mégpedig szivesen és szeretettel, hiszen igen jó kollektiva alakult ki, a segítókészség az oktatók, a vezetés, a kollégák és hallgatók részéról egyaránt mindennapi tapasztalatnak számított".

Az évtized végén, a dinamikus fejlesztés egyik utolsó állomása volt az 1999-ben elindított Gyógytornász Szak. Hazánkban 1975 óta létezik fooiskolai szintû gyógytornász szak. 1987-ig csak Budapesten az Orvostovábbképzó Egyetemen nyílt erre lehetőség, míg 1990-tôl a Szegedi és a Pécsi Orvostudományi Egyetem keretein belül is elindult a képzés. A két intézmény azonban nem tudta a szükséges szakemberutánpótlást biztosítani, így néhány év után szükségessé vált, hogy újabb helyszínen teremtődjenek meg a feltételek a képzéshez. Az évtized elején rövid ideig Miskolcon is múködött gyógytornász szak, ez azonban 1993-ban megszûnt, ez pedig azt jelentette, hogy az ország északi és keleti régiói szinte teljesen szakember-utánpótlás nélkül maradtak, így egyre sürgetőbbé vált a képzés beindítása.

A képzés Nyíregyházán indult volna, az indítás feltételei Debrecen kivételével Miskolcon és Nyíregyházán is megvoltak, de a felsőoktatás átszervezésének viharai Debrecenbe sodorták. A szakindítás engedélyeztetése Dr. Lipóczki Imre, Dr. Lukácskó Zsolt, Gardi Zsuzsa a Magyar Gyógytornászok Társasága elnöke, nyugalmazott fôiskolai docens, Tóth Lajos Tiborné nyugalmazott fóiskolai docens és Dr. Udvardy Miklós egyetemi tanár érdeme. Konkrét megszervezése Dr. Karmazsin László és Dr. Roberto Gomez nevéhez fúzôdik. Szepesi Kálmán professzor, a szak elsó igazgatója, így emlékezett vissza az indítás körülményeire:

„Magam, aki a szak alapitó igazgatója lettem, az Ortopédiai Klinika igazgató professzoraként éltem meg nemcsak klinikánk, de egész régiónk vonatkozásában a gyógytornászaink kicsiny létszámából adódó gondokat, és azt, hogy az idôsebb kollégák utánpótlására még lehetôséget sem láttunk. Sok évvel korábban volt ugyan Debrecenben gyógytornászképzés, és azok, akik még munkaképes korban voltak, nagyrészt ebból a forrásból származtak. Adminisztratív okokból azonban ezt a képzést városunkban sok évvel korábban megszüntették. Egyértelmú volt tehát a feladat, újra meg kell teremteni a képzés feltételeit ... Magán a szakon történö képzést helyettesemmel, Dr. Gomez Roberto föorvossal együtt kellett megszerveznünk. Ó vezetô föorvos volt a Gyógyfürdóben, és így közvetlenül tudta irányítani az ott dolgozó gyógytornászok tevékenységét, akiktól a hallgatók oktatását a szigorúbban vett gyógytornász tantárgyakban vártuk ... Az elméleti és klinikai tárgyak oktatását az egyetem Általános Orvosi Karának tanszékeitól kellett kérnünk, és ez az én feladatom volt. Jó érzés volt, hogy a vezetô professzorok megértették ennek a képzésnek a fontosságát, és kivétel nélkül készséggel vállalták tantárgyuk oktatásának biztosítását 
gyógytornászaink számára”.

Az 1998-as sikeres akkreditációt követően 1999 szeptemberében indult el a szak, debreceni helyszínnel.

Ahogyan arra Szepesi professzor is utalt, a debreceni gyógytornászképzésnek voltak már elôzményei. Erról korábban az elsố szakigazgató-helyettes, Dr. Gomez Roberto írt részletesebben egy publikációjában:

„A debreceni gyógytornászképzés története egészen az ötvenes évekre nyúlik viszsza. Ez idóben a Heine-Medin kór járványosan fordult elô hazánkban, nagy számú áldozatot követelve. A betegségben szenvedók ellátása érdekében 195\%-ben indult be elôször Debrecenben gyógytornászképzés, a budapesti képzés kihelyezett részeként. A képzés ideje 2 év volt, nappali illetve munka melletti tagozaton".

A képzés jellemzôen munka mellet folyt, hiszen, ahogyan arra Gardi Zsuzsa, a Magyar Gyógytornászok Társaságának korábbi elnöke egyik írásában utalt: „Munka melletti, mert délelótt a bénult betegeket kellett ellátni és csak délután volt idố az órák leadására".

Dr. Gomez Roberto írásából tudjuk, hogy az ekkor végzettek „gyógytornász oklevelet kaptak. A képzés a Debreceni Orvostudományi Egyetemen kapott helyet, a gyakorlatok azonban nagyrészt a Debreceni Gyógyfürdô Fizioterápiás Részlegén zajlottak.

Szakmai vezetôje Dr. Lutther Béláné, kiemelkedô gyógytornász személyiség volt. E kiváló szakember Dr. Madzsar Józsefné Jászi Alice tanítványaként a budapesti oktatás fö vonalait követte ... Az oktatásban föleg budapesti szakoktatók, illetve helyi professzorok, tanárok, klinikusok vettek részt, olyan kiemelkedố személyiségek, mint Prof. Dr. Pap Károly, Prof. Dr. Petrányi Gyula, Dr. Papp Zoltán és Dr. Kalapos Sándor".

Az oktatás egyik fô bázisa természetesen a fôiskolai képzés esetében is a Nagyerdei Gyógyfürdô volt, amely rendelkezett az oktatáshoz szükséges összes adottsággal és felszereléssel. A fürdőben megtalálható minden fizioterápiás eljárás (a balneoterápiától a fototerápiáig), amely szükséges a hallgatók oktatásához. A klinikai tárgyak oktatását természetesen az egyetemen belül kellett megoldani, ehhez elsô lépésben az Egyetem sugárúti épületben kapott meg a szak néhány helyiséget, végleges elhelyezését késóbb a Kassai úton felépült új épületszárny biztosította.

Az indításban a Magyar Gyógytornászok Társaságának vezetôi is aktívan segítettek, különösen Gardi Zsuzsanna, a társaság elnöke, illetve Gerencsér Zsuzsanna, aki ekkoriban a magyar társaságot képviselte a Nemzetközi Gyógytornász Szövetség egységes európai képzési standardjait kidolgozó bizottságában.

Mindezek alapján elmondható, hogy a kar elsô évtizedére a gyors és dinamikus fejlődés volt a jellemzô. Az újonnan indított szakok közül négy olyan is szerepelt a fốiskola kínálatában, amelyek korábban nem léteztek Magyarországon, így az elsô évtized az igazi "úttörômunka" jegyében telt. A tantervek kialakítása nemzetközi minták alapján történt, ez a munka azonban nemcsak egy egyszerú adaptációt jelentett, hanem személyes konzultációkat is olyan neves külföldi szakemberekkel, akik vállalták, hogy a helyszínen segítik a curriculumok kidolgozását. 
A kar alapító fóigazgatója, Dr. Lukácskó Zsolt az egyetem vezetésének, rektorainak bizalmát élvezte, hatalmas támogatást kapott munkájához. Körültekintő egyeztetéseket folytatott a szakok indításánál, a fejlesztéseknél, személyi döntéseknél, továbbá a kar adminisztrációs, pénzügyi rendszerének kialakításakor, valamint infrastruktúra fejlesztési ügyekben.

Számos jelentős, országos hatáskörű szakmai testületnek volt tagja (Egészségügyi Tudományos Tanács Felsőoktatási Bizottsága, Felsőoktatási Tudományos Tanács Tervezési és Finanszírozási Bizottsága, Felsőoktatási Fóigazgatói Konferencia vezetôsége, Szociális Szakképzési Bizottság stb.) - így kellő információval, rálátással rendelkezett és egyben érdekképviseleti lehetôséggel is bírt. Mindezek, továbbá a széles nemzetközi kapcsolatok (több mint húsz ország), a négy orvostudományi egyetem fóiskolai képzéseinek együttmúködése - és a megbízható helyi oktatói, gazdasági, adminisztratív háttér adta azt a lehetôséget, hogy dinamikusan fejlődhetett a nyíregyházi képzés.

Az első évekre így a nemzetközi kapcsolatok igen széles körú és rendkívül gyors bővülése is jellemzô volt. Már az Általános Szociális Munkás szak indításában is jelentôs szerepet vállaltak amerikai és német szakértôk, akik nemzetközi ösztöndíjak és pályázati programok támogatásával hosszú hónapokat töltöttek az intézményben. Hasonló módon került kialakításra az Egészségügyi Ügyvitelszervezô képzés tanterve, amelyben fooleg amerikai és holland szakértók vettek részt, illetve a Diplomás Ápoló szak programja. Ez utóbbi esetében már nemcsak tengerentúli szakértôk segítették a munkát, hanem több európai ország képviselői is, illetve egy olyan nemzetközi, az egyes kormányok közötti megállapodáson alapuló tantervfejlesztó program, amely egységesítette az egyes országok tanterveit és képzési szintjeit.

Ennek a fejlesztô munkának számos eredménye lett. Egyrészrôl mind az oktatók, mind a hallgatók számára természetessé vált, hogy külföldi szakértők, vendégoktatók folyamatosan jelen vannak a képzésekben, másrészrôl magától értetôdôvé vált, hogy az oktatók és a hallgatók egyaránt részt vehetnek nemzetközi tanulmányutakon, külföldi részképzésen és vendégoktatáson, jóval a Bologna-folyamat és az uniós csatlakozás előtt. A kormányközi támogatásnak és megállapodásoknak köszönhetően olyan képzési programok kerültek bevezetésre, amelynek eredményeképpen az egészségtudományi képzési területen szerzett hazai diplomák már ekkor automatikusan elfogadottak voltak a világ legtöbb országában.

A képzési kínálat dinamikus fejlôdését szemlélteti az alábbi áttekintő táblázat (1. táblázat) is, amely jól mutatja, hogy a tervezés, a főiskola vezetésének stratégiája szerint szinte évente rukkolt elô az intézmény valamilyen új szakkal.

A képzési kínálat bôvülése természetszerúleg járt együtt a hallgatói létszám dinamikus bôvülésével. A szakok iránt nagy volt az érdeklôdés, jellemzố volt a háromszoros, ötszörös, egyes képzések esetében a kilencszeres, tízszeres túljelentkezés. Ez részben növelte az államilag finanszírozott nappali képzésekre felvehetô létszámokat, részben, az évtized közepétôl egyes szakokon a képzési kínálat a levelezô tagozatok elindításával is bôvült, amely részben növelte a hallgatók összlétszámát, részben a költségtérítéses képzésben résztvevookét. Míg 1990-ben a hallgatói össz- 
létszám 60 fő volt, addig 1995-re már közel ezer hallgató járt a főiskolára.

Az intézmény így néhány év után már helyhiánnyal küzdött, hiszen a Sóstói úti épület egyre szúkösebbnek bizonyult. A kezdeti idôszakban az épület ugyanis nemcsak oktatási épületként funkcionált, itt került kialakításra a fóiskola kollégiuma is, amely 50 fố befogadását tette lehetôvé. Természetes látvány volt, hogy a hallgatók papucsban járnak az órákra. Ahogyan arra Vitál Attila, a Hallgatói Önkormányzat második elnöke egyik írásában utalt, a nyíregyházi diákok igencsak irigyelték kollégista társaikat, „hiszen az órák kezdete elótt elegendó volt öt perccel hamarabb ébredniük, s a lyukas óráikat a saját ágyukban tölthették. Mondhatom családias volt a légkör, néhány hét alatt valamennyien ismertük egymást".

1. táblázat: A képzési kínálat alakulása a Debreceni Orvostudományi Egyetem Egészségügyi Főiskoláján, 1990-2000.

\begin{tabular}{|c|c|c|c|}
\hline $\begin{array}{l}\text { Az indítás } \\
\text { éve }\end{array}$ & $\mathrm{Az}$ indított szak & A képzés helye & $\begin{array}{l}\text { Az elsó évfolyamra } \\
\text { felvételt nyert } \\
\text { hallgatók létszáma }\end{array}$ \\
\hline 1990 & $\begin{array}{c}\text { Általános Szociális } \\
\text { Munkás }\end{array}$ & Nyíregyháza & 30 \\
\hline 1990 & Védônô & Nyíregyháza & 30 \\
\hline 1991 & $\begin{array}{c}\text { Egészségügyi } \\
\text { Ügyvitelszervezó }\end{array}$ & Nyíregyháza & 21 \\
\hline 1993 & Diplomás Ápoló & $\begin{array}{l}\text { Nyíregyháza } \\
\text { és Gyula }\end{array}$ & $39+43$ \\
\hline 1997 & $\begin{array}{c}\text { Orvosdiagnosztikai } \\
\text { Laboratóriumi Analitikus }\end{array}$ & Debrecen & 41 \\
\hline 1998 & Mentőtiszt & Nyíregyháza & 39 \\
\hline 1999 & Gyógytornász & Debrecen & 57 \\
\hline
\end{tabular}

Az elhelyezési gondok megoldására a fôiskola vezetése tárgyalásokat kezdett a megye és a város vezetóivel, melynek eredményeképpen az intézmény kollégiumi célra megkapta a Bethlen Gábor utcán lévô, és korábban a Kelet-Magyarországi Állami Építőipari Vállalat munkásszállójaként múködő épületegyüttest, oly módon, hogy az épületet 1992-ben Szabolcs-Szatmár-Bereg Megye Közgyúlése és Nyíregyháza város önkormányzata fele-fele részben megvásárolta a Debreceni Orvostudományi Egyetem részére és átadta a karnak. Az új kollégium kialakítása, bôvítése és átalakítása 1992 és 1998 között zajlott le. Azonnali átalakítással 150 fơ elhelyezésére nyílt lehetôség, mivel az 1976-ban átadott épület igen elhanyagolt állapotban volt. Korszerúsítést nem végeztek rajta, elektromos hálózata korszerútlen volt, a nyomó- és lefolyó vezetékek elavultak, a beázás állandósult, konyhai berendezései erôsen elhasználódtak. A gyors átalakítást követően 1995-ben tetôtér beépítéssel újabb 54 féróhellyel bôvült a létesítmény. 1998-ban a korábbi konyhai rész átalakításával újabb 50 fő elhelyezésére nyílt lehetôség. 
Az évtized során hasonló ütemben folyt a tanügyi épületegyüttes átalakítása és bővítése. Elkészült a Sóstói úti épület rekonstrukciója és tetőtéri beépítése, amellyel megszületett a "főépület" ma ismert arculata, és amely 1570 m2-el bóvítette az épület alapterületét. 12 tanterem, 26 irodahelyiség, néhány vendégszoba és szociális helyiségek átadására került sor. A megyei önkormányzat 1997 év végi döntése alapján a korábbi Gyermek és Ifjúságvédő Intézet szomszédos épületének átadása is lezajlott. Ez az épület eredetileg bentlakásos gyermekotthon volt, melyet a gyermekvédelem megváltozott jogszabályi feltételrendszere miatt a megye megszüntetett, így az átadás nem zavarta meg az intézmény múködését.

Az épület elég leromlott és elhanyagolt állapotban volt, amit a kar 1999-ben saját erôból, tetootér ráépítéssel felújított. Az alapterület jelentősen bôvült (1894 m2), itt kaptak elhelyezést a mentôtiszt, az ápoló és a védőnő képzések speciális szaktantermei, az új könyvtár és az ebédló.

A dinamikus fejlődésnek köszönhetôen 1995-ben jogi-szervezeti változás is bekövetkezett, hiszen jelentôs elismerésben részesült az intézmény azzal, hogy elnyerte a kari státuszt. Ennek értelmében elnevezése is a Debreceni Orvostudományi Egyetem Egészségügyi Fôiskolai Kara lett. Muszbek László professzor, akadémikus, az egyetem akkori rektora így nyilatkozott erról egyik írásában:

„Az intézmény fejlesztési koncepciója összhangban áll mind az európai egészségügyi és szociális ellátási rendszerek minöségi követelményeivel, mind a hazai egészségügyi reformtörekvések körvonalazódó elképzeléseivel, igényeivel.

Elismeréssel nyilatkozhatunk vezetô elödeink azon törekvéséról, amely annak idején örömmel vállalta a föiskola befogadását és minden eszközzel támogatta annak fejlesztését. Bölcs és megalapozott döntésként üdvözöljük fóhatóságunk minôsitését, amely a fiatal föiskolát egyetemünk egyik karává léptette elő. Mi, az egyetem jelenlegi vezetöi a föiskolai kart a Debreceni Orvostudományi Egyetem szerves részének tekintjük, és kedves kötelességünknek tartjuk, hogy minden lehetố eszközzel biztositsuk e fiatal intézmény töretlen, dinamikus fejlödését".

A képzési kínálat és az infrastruktúra bơvítésének időszakában esett át az intézmény az elsố akkreditáción is, 1996-ban. A minôsítés sikeres volt, az Országos Akkreditációs Bizottság kiválóra értékelte a kar munkáját, európai színvonalúnak és iskolateremtőnek minôsítve azt. Különös súlyt adott ennek a véleménynek az, hogy a neves tudósokból álló Látogató Bizottságot Dr. Vízi E. Szilveszter a Magyar Tudományos Akadémia akkori alelnöke, késôbbi elnöke, orvos-akadémikus vezette.

A bizottság elnöke írásos értékelésében a következőképpen írt a kar munkájáról: „A Nyíregyházára kihelyezett Egészségügyi Föiskolai Kar rendkívül jól szervezett, professzionálisan vezetett intézmény. Szerencsésen ötvözödik a Debreceni Orvostudományi Egyetemmel. Különösen a gyakorlati képzése kiemelendō...Az egyetem és a föiskolai kar oktatóinak szoros együttmüködése teszi lehetôvé a képesítési követelményekben megfogalmazott elvárások magas szintü teljesítését. Az oktatás feltételei mind a szociális szférában, mind az egészségügyi ellátó rendszerben egyaránt megfelelnek a képesitési követelményeknek és esetenként európai szinvonalat biztosítanak". 
Abban az időszakban még szokatlan módon, az akkreditációs folyamatban, a karral rendszeres kapcsolatot tartó külföldi szakemberek is részletes szakmai értékelést adtak az intézményben folyó oktatási munkáról. Prof. Dr. Israel Sela, (az amerikai A.J.D.C. Joint szervezet magyarországi igazgatója) így fogalmazott: „Programjuk Magyarország más intézményeihez viszonyítva rendkívül szinvonalas és bármelyik nyugati országban megállja a helyét".

Dr. Gotthart Schwarz, a müncheni Fachhochschule professzora véleménye szerint: „Imponáló, hogy - Magyarország nehéz általános helyzete ellenére - igen rövid idô alatt sikerült egy új föiskola számára koncepcionális szervezeti, financiális, technikai és személyi alapokat létrehozni és stabilizálni. Nézetem szerint ez a fejlödés a modern intézményvezetés sikeres példája".

Norbert Lippenmeier, a Kasseli Egyetem vezető oktatója a következóképpen vélekedett: „A DOTE nyíregyházi Egészségügyi Fóiskoláján modern, a nyugat-európai színvonalnak megfeleló, a társadalmi változásokra rugalmasan reagáló képzés folyik...Az oktatás szintje hazai vonatkozásban vezető helyen van, nemzetközileg pedig kiállja az összehasonlitás próbáját a nyugat-európai oktatási intézményekkel”.

Az intézmény történetének első évtizede nemcsak a karrá nyilvánítás, a kiválóra minősített akkreditációs értékelés és a folyamatos képzésfejlesztés miatt tekinthető sikeresnek. Ekkor alakultak ki azok a hazai és nemzetközi kapcsolatok is, amelyek meghatározói lettek az intézmény késóbbi fejlődésének.

\section{A képzés fôbb vonásai. Az ezredforduló változásai, strukturális átalakítások és a minôségi fejlesztés le- hetôségei}

A képzésfejlesztés közel egy évtizedének lendületét megtörték azok az átalakítások, amelyek alapjaiban változtatták meg a hazai felsôoktatási rendszert. Az 1998-ban megválasztott kormány programjába foglalta a felsőoktatási intézmények átalakítását, pontosabban integrációját. Az első döntések alapján az egészségügyi főiskolai kar a létrehozandó Nyíregyházi Fóiskola részeként múködött volna tovább. Ez a döntés erôteljes ellenkezést váltott ki nemcsak a karon, hanem az anyaegyetemen, illetve a legkülönbözóbb szakmai szervezeteknél is.

Az átalakítás koncepciója nem számított teljesen újnak, hiszen már az 1990ben és 1994-ben megválasztott kormányok is célul tûzték ki a rendszer átalakítását. A reformelképzelések helyi megvalósítására már az évtized elsó éveiben szoros együttmúködés alakult ki a városban múködô intézmények között. A Nyíregyházán múködő, akkor még négy felsôoktatási intézmény (Bessenyei György Tanárképzô Főiskola, a GATE Mezőgazdasági Főiskolai Kara, a Szent Atanáz Görög Katolikus Hittudományi Fóiskola, illetve a Debreceni Orvostudományi Egyetem Egészségügyi Fôiskolája) egyetértve az átalakítási elképzelésekkel, a szakmai és a regionális érdekeket figyelembe véve, önként - országos modellként is az elsók között - már 
1991-ben létrehozták a Nyíregyházi Fơiskolai Egyesületet, amelynek első elnökét éppen az Egészségügyi Fôiskola adta, Dr. Karmazsin László professzor személyében.

Az egyesület alapvető célja a reformfolyamatok helyi-regionális megvalósítása volt, egy szoros és a kölcsönös előnyöket keresô együttmúködés formájában. A közös munka egyik legfontosabb eredménye az a megállapodás volt, amely 1995-ben jött létre. Az intézmények között egy olyan egyezség született, amelynek értelmében a késóbbiekben a tanárképző és a mezőgazdasági fôiiskola egységesen integrált intézményi szervezetben fog együttmúködni, melyhez a hittudományi és az egészségügyi főiskolák, elsődlegesen szakmai indokok miatt nem csatlakoznak, de bizonyos területeket, kollégium, sport, kultúra, nyelvi képzés stb. közösen múködtetnek.

Hasonló véleményt képviseltek a debreceni egyetemek is, akik az elsó pillanattól az integráció mellett foglaltak állást. Olyan ésszerú struktúra kialakításán dolgoztak, ahol a kölcsönös elônyök kihasználása, a hagyományok megórzése, a legkisebb egységek érdekeinek tiszteletben tartása volt a cél. Az elképzelés kimunkálásának elörehaladásával körvonalazódni látszott egy „Kelet-Magyarországi Egyetem”, ahol a debreceni (inkább egyetemi) képzéshez egy erôs (inkább nyíregyházi) fôiskolai centrum csatlakozik. Az egyetemek támogatták ezt az elképzelést, még oly módon is, hogy a főiskolai karok és szakok megerôsítésével az egyetemi diploma adásának lehetőségét is reálisnak tartották a főiskolai karokon.

Ezt az alapvetóen alulról szerveződő folyamatot törte meg az 1998-as kormányzati elképzelés, melynek lényege az „egy város, egy intézmény volt”, és amely részben figyelmen kívül hagyta a helyi-regionális és különösen a szakmai érdekeket.

Az Egészségügyi Minisztérium is tiltakozását fejezte ki, hivatalos állásfoglalása szerint ugyanis egészségügyi felsőoktatás nem létezhet orvostudományi egyetemi háttér nélkül, illetve egységes rendszerként értelmezve a gyógyítást és az egészségügyi képzést annak közös struktúrában kell múködnie, biztosítva a szakmai irányítás, a képzés és a minőségbiztosítás teljes összhangját. A Magyar Akkreditációs Bizottság, a Felsőoktatási Tudományos Tanács, az Egészségügyi Tudományos Tanács, a Magyar Rektori Konferencia szintén az elképzelés ellen foglalt állást.

A kar kiállt a szakmai érdekek mellett. A Kari Tanács 1996-ban hozott állásfoglalása szerint az intézmény „... szakmai müködtetése az egyetemtól elválasztva elképzelhetetlen ... a Kar a Debreceni Egyetemi Szövetségben kívánja munkáját folytatni".

Az Orvostudományi Egyetem Tanácsa 1998-ban szintén a kar leválasztása ellen foglalt állást. A határozatokat figyelmen kívül hagyták, a koncepció változatlanul a Nyíregyházi Fóiskolához sorolta a kart. Ez az elképzelés abból a szempontból is problematikus volt, mert ellentmondott az integrációra vonatkozó alapvetó kormányzati szándékokkal, azaz a saját maga által képviselt elvekkel, hiszen az egészségügyi karok leválasztása a többi hazai orvostudományi egyetemnél szóba sem került, kizárólag Nyíregyháza esetében.

Az országossá váló vitában a kar egy idô után kiemelt helyre került, a sajtó, a rádiók és televíziók slágertémája lett, alig volt olyan szakmai fórum, vita, ahol 
példakánt ne került volna szóba.

Muszbek László rektor összefogásával, irányításával, közös erőfeszítéssel sikerült olyan erôket mozgósítani, hogy az igen széleskörú tiltakozás hatására az Oktatási Minisztérium végül felülbírálta álláspontját, így az intézmény az integrált Debreceni Egyetem Egészségügyi Főiskolai Karaként, illetve az egyetemen belül létrejött új struktúrában, az Orvos-és Egészségtudományi Centrum szervezeti egységeként múködött tovább 2000 szeptember elejétől. Az integráció természetesen érintette a kar belső szervezeti felépítését is. Bár a szakigazgatói rendszer továbbra is megmaradt, hiszen elsődlegesen ók voltak a felelősei a szakmai munkának, a 2000/2001-es tanévben létrejött a kar elsố tanszéki struktúrája, az egyes tudományterületek oktatási, kutatási feladatainak minél sikeresebb múködtetése érdekében. A kar elsô tanszékeit még a Debreceni Orvostudományi Egyetem alapította, vezetóit azonban már a 2000. január 1-jén létrejött Debreceni Egyetem Tanácsának jóváhagyó javaslatára nevezték ki. (2. táblázat)

2. táblázat: A Debreceni Egyetem Egészségügyi Főiskolai Karának elsô tanszékei és vezetői, 2000.

\begin{tabular}{|l|l|}
\hline Tanszék & Tanszékvezető \\
\hline $\begin{array}{l}\text { Alkalmazott Társadalom } \\
\text {-és Egészségtudományi Tanszék }\end{array}$ & Dr. Cselényi István főiskolai docens \\
\hline Ápolási Tanszék & Dr. Szabó Tünde főiskolai docens \\
\hline Egészségügyi Informatikai Tanszék & Dr. Koós István főiskolai docens \\
\hline $\begin{array}{l}\text { Egészségügyi Ügyviteli } \\
\text { és Finanszírozáselméleti Tanszék }\end{array}$ & Dr. Zagyi Bertalan fooiskolai docens \\
\hline Fizioterápiás Tanszék & Dr. Roberto Gomez főiskolai docens \\
\hline Klinikai Kémiai Analitikai Tanszék & Dr. Góth László fóiskolai tanár \\
\hline Oxyológiai Tanszék & Dr. Szép Imre fóiskolai docens \\
\hline $\begin{array}{l}\text { Szociális és Egészségtudományi } \\
\text { Alkalmazott Pszichológiai Tanszék }\end{array}$ & Dr. Kiss János fóiskolai docens \\
\hline Szociális Munka Tanszék & Dr. Horváth László fóiskolai docens \\
\hline Transzfúziológiai Tanszék & Dr. Meggyesi Ildikó fóiskolai docens \\
\hline Védônoói Prevenciós Tanszék & Kalapos István fôiskolai tanár \\
\hline
\end{tabular}

Az integrációs folyamat a kar képzései közül elsődlegesen a Diplomás Ápoló szakot érintette. A kilencvenes évek végén már érzékelhetô volt, hogy a gyulai nappali tagozatos képzés nem tartható fenn korábbi formájában. Mivel ekkor már konkretizálódott, hogy a Debreceni Orvostudományi Egyetem, illetve jogutódja milyen regionális szakmai feladatokat fog ellátni, illetve várható volt a finanszírozási rendszer átalakítása is, a kar és az egyetem vezetése, Gyula város önkormányzatával egyetértésben 1999 novemberében megszúntette a gyulai kihelyezett képzést.

Az egyetem szakmai feladatai ugyanis négy megyére (Hajdú-Bihar, Heves, Borsod-Abaúj-Zemplén és Szabolcs-Szatmár-Bereg) terjedtek ki, melyból Gyula már 
ekkor „kilógott”. A négy megye egészségügyi intézményei már ekkoriban is sürgették a nappali tagozat nyíregyházi indítását. Bonyolította a helyzetet, hogy a gyulai képzésben résztvevôk jelentôs része ezekbool a régiókból került ki, és a nagy távolságra, illetve anyagi gondokra hivatkozva egyre többen kérték, hogy képzésük Nyíregyházán valósuljon meg.

Még jelentősebb indok volt a normatív finanszírozás bevezetése, ami azt jelentette, hogy egy szak két képzési helyen és két képzési formában való múködtetése gyakorlatilag finanszírozhatatlanná vált.

A gyulai ápolóképzés végül is nem halt el, az integráció révén létrejött Tessedik Sámuel Fôiskola szerves részévé vált, ahol az oktatás napjainkban is színvonalasan folyik.

Az átszervezést személyi változások is követték. Dr. Dankó Miklóst, aki folytatta a gyulai képzés irányítását, új szakigazgatóval kellett pótolni. A képzés irányítását először Prof. Dr. Szegedi Gyula akadémikus vállalta, néhány év után követte ôt Prof. Dr. Kakuk György, majd a késóbbiekben Dr. Bodolay Edit, mindannyian a debreceni orvosképzés jeles személyiségei.

A változások a kar védônô képzését is érintették, igaz teljesen más formában. Miskolcon 1987 és 1995 között már múködött védőnóképzés a Haynal Imre Egészségtudományi Egyetem Egészségügyi Fôiskolai Karának kihelyezett tagozataként, gyógytornászképzéssel együtt. A tagozatot 1995-ben megszúntették, ami nagymértékú szakemberhiányt okozott a városban és a megyében. Ennek felismeréseként a Miskolci Egyetem kezdeményezte a védônőképzés újraindítását, oly módon, hogy a szak 1998 és 2001 között a Debreceni Egyetem Egészségügyi Fóiskolai Kar miskolci kihelyezett tagozataként múködött, vagyis a kar biztosította a szakmai és tudományos hátteret. A képzés, irányítását, szervezését ebben az idôszakban Dr. Peja Márta osztályvezetô foóorvos látta el.

2001. szeptemberétól a képzést teljes egészében átvette a Miskolci Egyetem, megteremtve ezzel a késóbb, 2005-ben létrehozott Egészségügyi Fóiskolai Kar alapjait. A kar ma az egyetem egészségügyi karaként múködik, a szakmai kapcsolat azonban nem szûnt meg, a két intézmény számos formában múködik együtt napjainkban is.

A nyíregyházi védőnóképzés irányítását ekkor már Prof. Dr. Lampé László látta el, feladatait a késóbbiekben Dr. Orosz Tóth Miklós vette át, aki egy idóben a kar főigazgatója is volt. A szak jelenlegi felelős vezetője Dr. Kósa Zsigmond.

Hasonló személyi változások zajlottak le az Egészségügyi Ügyvitelszervezó Szak esetében is. A szak igazgatója hosszú időn keresztül Dr. Zagyi Bertalan volt, oot követte 2001 és 2003 között Dr. Koós István, majd néhány évig Pethô Attila professzor, egyetemi tanár, a szak jelenlegi vezetôje Dr. Ködmön József.

Változás történt az Általános Szociális Munkás, a Gyógytornász, illetve az Orvosdiagnosztikai Laboratóriumi Analitikus szakok élén is. Az integrációt követóen a szociális képzés felelôs vezetôje Dr. Imre Sándor egyetemi docens lett, ôt követte Dr. Molnár Péter professzor, egyetemi tanár. Napjainkban a szak felelôs vezetője Dr. Fábián Gergely fóiskolai tanár. A gyógytornász képzés esetében Szepesi 
Kálmán professzort Dr. Cseri Julianna főiskolai tanár, az ODLA szaknál Muszbek László akadémikus egyetemi tanárt pedig Prof. Dr. Módis László váltotta.

A strukturális átalakítások sorát bôvítette a felsôoktatási rendszer európai és hazai reformja, ideértve a kreditrendszer bevezetését és a Bologna-dekrétum aláírását 1999-ben. Ehhez társult hazánkban az új felsőoktatási törvény, illetve annak elfogadásával párhuzamosan a finanszírozási rendszer átalakítása. A Bolognafolyamathoz társulva, a Nemzeti Bologna Bizottságnak a hazai "szakburjánzást" megállítását szolgáló döntései alapján Magyarországon jelentősen megváltozott a szakok (az új definíciók szerint az alapképzések) struktúrája is, így a 2000 és 2006 közötti időszak az intézmény esetében alapvetően a szerkezeti átállás jegyében telt, hiszen a képzések tanterveit folyamatosan módosítani kellett. Ebben az időszakban voltak olyan tanévek a kar életében, mikor egy-egy szakon 2-3 tanterv is érvényben volt.

Az átalakítások eredményeképpen a korábban önálló szakként múködő képzések nagyobb alapszakokká integrálódtak, több szakirány definiálásával. Így alakult ki a karon a ma is múködô új képzési struktúra, amely négy alapszakot és összességében 7 szakirányt jelent. (3. táblázat)

3. táblázat: A Debreceni Egyetem Egészségügyi Főiskolai Karának új képzési struktúrája.

\begin{tabular}{|l|l|}
\hline Alapszak & Szakirányok \\
\hline Ápolás és Betegellátás & $\begin{array}{l}\text { Ápoló, Szülésznő, Mentootiszt, } \\
\text { Gyógytornász }\end{array}$ \\
\hline Egészségügyi Gondozás és Prevenció & Védőnő \\
\hline Egészségügyi Szervezô & $\begin{array}{l}\text { Egészségügyi Ügyvitelszervezô, } \\
\text { Egészségbiztosítás, Egészségturizmus }\end{array}$ \\
\hline Szociális Munka & \\
\hline
\end{tabular}

Az átalakulás folyamán egyes képzések elnevezései is módosultak, így lett a korábbi Általános Szociális Munkás képzésból Szociális Munka Alapszak (a végleges döntés szerint szakirányok nékül), az Egészségügyi Ügyvitelszervező szakból pedig Egészségügyi Szervezô. Ez utóbbi esetében a karon a szakhoz tartozó szakirányokat is létre kellett hozni.

A helyzetet némiképp bonyolította, hogy az Egészségügyi Gondozás és Prevenció alapszakhoz került besorolásra a védőnő mellett az ún. népegészségügyi ellenôr szakirány is, amely soha nem múködött a karon, feleloos szervezóje az egyetemen mindig is a Népegészségügyi Kar volt. Ez a helyzet újabb együttmúködési formákat alakított ki az Orvos-és Egészségtudományi Centrumon belül.

Bár a Bologna-folyamat hazánkban az egészségtudományi képzéseket általában abban az értelemben nem érintette, hogy rövidült volna a képzési idő (továbbra is 8 féléves képzésekrôl van szó, szemben a Bologna által definiált $3+2$ éves osztott képzési rendszerrel, amelyben a három éves alapképzésekre épülnek rá a két éves 
egyetemi diplomát adó mesterképzések), a karon folyó képzések integrált tanterveit ki kellett dolgozni, illetve minden képzést mint „bolognai alapszakot” újra kellett akkreditáltatni, ami újabb energiákat vont el a további képzésfejlesztésektól.

A képzési idő a Szociális Munka és az Egészségügyi Szervező alapszakok esetében lett rövidebb, mindkét esetben egy 7 féléves struktúra alakult ki, a szociális munkás képzésben egy félév intenzív, intézményen kívüli gyakorlati félévvel.

A szakok akkreditációjával szinte egy idóben, 2006-ban került sor az újabb intézményi akkreditációra is, amely már sokkal részletesebb és szigorúbb volt, mint tíz évvel azelôtti elôdje. A kar mindkét folyamatot sikeresen lebonyolította, újra kiváló minősítést kapott, így az új struktúra kialakítása után ismét elérkezett az idő, amikor újra a jövô tervezése válhatott a legfontosabb stratégiai feladattá.

Az intézmény elsôsorban a Bologna-rendszerben meglévô lehetôségeket igyekezett kihasználni. Bár az új egységes európai rendszer bevezetése óta a viták kereszttüzében áll, nemzetközi szinten is, és újragondolása is egyre aktuálisabbnak tûnik, a hazai polémiákban a strukturális kérdések sajátosan keveredtek a finanszírozási anomáliákkal, illetve az egyre tömegesebbé váló felsőoktatás problémáival, ami megnehezítette a tisztán a szerkezeti változásokra vonatkozó párbeszéd kialakulását. Sok hazai intézmény kényszerként és hátrányként élte meg a változásokat és gyakran elmerült a végeérhetetlennek tûnô vitákban, fórumokban.

A kar, amennyire arra mód és lehetôség volt, próbálta elkerülni ezeket a vitákat, igyekezett önálló és az intézmény sajátosságait is figyelembe vevô stratégiai tervet kidolgozni. Ehhez számos tényezót kellett számba venni, amelyekről már ekkor tudható volt, hogy jelentősen befolyásolják majd a felsőoktatás helyzetét. Ilyen körülmény hazánk demográfiai helyzete, a rendszer finanszírozásának permanens nehézségei, az egyre szigorúbb akkreditációs követelmények és az uniós tagságból is származó erôteljes nemzetközi kihívások. A stratégia központi eleme a már kialakult alapszaki struktúrára épülő speciális mesterszakok és továbbképzési programok kidolgozása volt, amelyben az alapképzés tartalmi fejlesztése természetes és folyamatos feladat, a mesterképzések esetében pedig kizárólag a kar profiljához illeszkedô, lehetôleg újdonság értékư képzések bevezetése volt. Ez egyben a kezdetekhez való visszanyúlást is jelentette, az "úttörô" szerep újravállalását, hiszen az intézmény olyan mesterszakok és szakirányú továbbképzések indítását tûzte ki célul, amelyek korábban nem léteztek Magyarországon, ugyanakkor az évtized második felében már érzékelhetô volt az irántuk megnyilvánuló szakmai és munkaerô-piaci kereslet.

A stratégiai elképzeléseket siker koronázta. 2007-ben a kar alapította meg az Egészségügyi Szociális Munka elnevezésû mesterszakot, amely korábban nem létezett hazánkban. A szak kezdeményezője Dr. Lukácskó Zsolt volt, szakmai előkészítését Dr. Fábián Gergely végezte, majd hosszas ellenállást és értetlenséget követôen, kemény viták után, a MAB fórum hozzáállása döntött. 2008-ban az új szak már országosan a harmadik legnépszerúbb mesterképzés volt az elsô helyes jelentkezések alapján.

A mesterszakot a kar szintén nemzetközi példák alapján hozta létre. Az egész- 
ségügy területén végzett szociális munkának elsôsorban az Egyesült Államokban van, napjainkban már több mint száz évre visszatekintő hagyománya, melynek értelmében az amerikai kontinensen már kialakultak a vonatkozó képzések is, elsôdlegesen mesterszakok formájában. Egyes ázsiai országokban is találhatók hasonló példák, Európában a Bologna-folyamatot megelôzố időszakban az alapképzésekhez integráltan jelentek meg az egészségügyi szociális munka tartalmai, azt követôen pedig elsôsorban a német nyelvterületen jöttek létre az első mesterszakok, egységesen klinikai szociális munka elnevezéssel.

A szak célja olyan szakemberek képzése, akik az egészség- és társadalomtudományok területén megszerzett elméleti és módszertani ismereteik birtokában képesek az egészségügyi és szociális problémák kezelésére a szakmai, a társadalmi és az ágazatközi együttmúködés során. A végzettek aktív résztvevőivé válnak a preventív tevékenységeknek és az akut problémák megoldására irányuló tevékenységi formáknak, illetve az utógondozásnak.

A curriculum kidolgozásához, illetve annak érdekében, hogy a képzés megfeleljen a nemzetközi standardoknak, a szakot alapító oktatók 2007-ben szakmai látogatást tettek több amerikai egyetemen, egészségügyi és szociális intézményben, hogy tanulmányozzák az egészségügy területén végzett szociális feladatokat, a gyógyító team közös munkáját, illetve előadásokat is tartottak egy olyan közös tudományos konferencián is, amely az egészségügyi szociális munka aktuális kérdéseit tárgyalta. Annak érdekében, hogy a képzés tartalma és színvonala megfeleljen a nemzetközi elvárásoknak, a szakterület ismert és elismert professzoraiból a kar létrehozott egy nemzetközi tanácsadó testületet (amerikai, német, cseh és finn oktatókból), amelynek tagjai folyamatosan figyelemmel kísérik az oktatás minőségét, segítik a szak curriculum-fejlesztési, tananyag fejlesztési programját, közremúködnek összehasonlító kutatási programok lebonyolításában, illetve a képzést segítő szakkönyvsorozat egyes köteteinek szerkesztésében és kiadásában.

A 2010-ben végzett elsô évfolyam egyik volt hallgatója szerint a képzés erôssége a sokirányú, ugyanakkor a komplexitásra törekvő szakirányú tudás átadása, az interdiszciplináris szemlélet.

„A képzést azoknak ajánlom, akik a gyakorlatban maguk is megtapasztalták az egyes szakterületek és ágazatok között megvalósuló együttmúködési nehézségeket, s akik ezen változtatni szeretnének. Véleményem szerint elmozdulást csak átfogó, multidiszciplináris, a klienseink érdekeit szolgáló team munka képes hozni. Meggyôzoódésem, hogy az egészségügyi szociális munka mesterképzés új dimenziót nyit a szociális munkában."

A szak elsô felelős vezetôje Prof. Dr. Bakó Gyula volt, 2011 szeptemberétől pedig Dr. Szoboszlai Katalin.

2010 szeptemberében indította útjára az intézmény az Ápolás mesterszakot, szintén nemzetközi és hazai előzmények alapján. A világ fejlett országaiban már évtizedek óta létezik ápolástudományi mesterképzés, általában „Master in Nursing Sciences" elnevezéssel. Ezen a területen hazánkat több rendszerváltó ország is megelőzte, hiszen pl. Csehországban, Szlovákiában már a kilencvenes évek elején 
létrehozták az ápolás mesterképzéseket, sôt több országban a szakra építve alapították meg az ápolástudományi doktori iskolákat. A mesterszak hazai előzményének a Pécsi Tudományegyetem Egészségügyi Fôiskolai Karán 2000-ben létrehozott, egyetemi szintú ápolóképzés tekinthetô.

A szak célkitűzése olyan egészségtudományi szakemberek képzése, akik ismerik a hazai egészségügy múködését, az ápolás közép- és felsôszintű intézményrendszerét, az egészségtudomány szerepét és fejlesztésének lehetőségét a társadalom életében. Alkalmasak az ápolás-szervezésre, intézményi osztályvezetésre, ápolásmenedzsmentre, ápoláskutatásra, az ápolás elméleti és gyakorlati oktatásának végzésére az ápolás tudományos problémáinak megoldásában, új ápolási ismeretek felkutatásában és gyakorlati hasznosításuk elômozdításában történô hatékony részvételre. A szak hazánkban, tekintettel az alapképzés 8 féléves időtartamára, három féléves mesterszakként került bevezetésre, elsô felelőse a karon Dr. Dankó Katalin.

2011 februárjában egy igen speciális mesterképzést indíthatott a kar, amellyel bizonyos szempontból „felsôoktatási történelmet írt”, hiszen a Bologna-rendszer bevezetése után elsóként akkreditáltatott hazánkban nemzetközi közös mesterszakot, Szociális Munka és Szociális Gazdaság elnevezéssel. A képzés 9 európai egyetem együttmúködésében valósul meg, a partnerországok: Ausztria, Németország, Svájc, Franciaország, Lengyelország, Csehország, Szlovákia és Románia. A szak ún. joint képzés, amelynek végén a hallgatók nemzeti és közös diplomát is kapnak, mivel a curriculum egységes minden közremúködô intézményben.

A SOWOSEC (Social Work and Social Economy) képzés története egészen 2003-ra nyúlik vissza, amikor is a kar szociális munkás képzésének oktatói egy nemzetközi program közremúködőiként szorosabb kapcsolatot alakítottak ki a bécsi FH-Campus Wien intézményével, ahol a késóbbiekben a képzés ötlete született. Az osztrák kollégák kezdeményezésére alakult meg az a nemzetközi curriculumfejlesztő csoport, amely egy sikeres uniós pályázatnak köszönhetően 2006 és 2009 között együttesen dolgozta ki a mesterszak programját, és amelybe a nyíregyházi intézmény elsóként kapott meghívást, még 2005-ben.

A szak programját elsóként Csehországban, ezt követően Ausztriában, majd hazánkban akkreditálták. A tantervet a csoport számos ülésen dolgozta ki, többek között Nyíregyházán, ahol két alkalommal is tanácskozott a nemzetközi grémium. Prof. Dr. Christine Gruber, a nemzetközi csoport vezetője a következóképpen foglalta össze egyik interjújában a képzés filozófiáját:

„Napjaink aktuális és igen gyors változásai megkövetelik, hogy a szociális szférában múködő szervezetek összekössék a gazdálkodást és a szociális segítségnyújtást. A cél az, hogy a szociális munkára jellemzố professzionális gondozást alapos gazdasági tervezéssel biztosítsuk, illetve bóvítsük. A szociális gazdaság területén müködő modern szervezetek eredményes vezetéséhez ugyanakkor szükség van nemzetközi együttmüködésre, az európai változások iránti érzékenységre.

A képzés filozófiája roppant bonyolultan, és rendkívül egyszerúen is megfogalmazható: az állami források csökkenésének korszakában a képzóknek és a gyakorlatban dolgozóknak egyaránt fel kell készülniük arra, hogy a gyorsan változó körülmények- 
hez igazodva is sikeresen menedzseljék intézményüket, forrásokat szerezzenek meg, tervszerüen gazdálkodjanak, tegyék közismertté szervezetüket, programjaikat és szolgáltatásaikat. Mindez azt jelenti, hogy nemcsak a szociális munka ismereteit és standardjait kell elsajátítaniuk (ezt képviseli a szociális munka alapképzés), hanem meg kell tanulniuk sikeresen gazdálkodni.

Mesterszakunk e két terület néha eltérô filozófiáját házasítja össze, a szakmák szempontjából és európai kitekintésben."

A hazai képzés felelôs vezetôje Dr. Fábián Gergely lett. A mesterszak indítása több hazai, szakmai szervezet érdeklődését is kiváltotta. Még nem is volt a képzésnek hallgatója, mikor 2010-ben, a sikeres akkreditáció után, a szak már kitüntetésben részesült, elnyerte a Szociális Innováció Alapítvány, az Általános Vállalkozási Fóiskola, valamint az MSD Magyarország Kft. által létrehozott Pro Bono díjat, mellyel azokat az innovatív programokat ismerik el évente egy alkalommal, amelyek jelentősen hozzájárulnak a hazai szociális gazdaság fejlődéséhez.

A mesterszakos, vagy egyetemi diploma kiadására való jogosultság megszerzése után az intézmény státusza és elnevezése is módosult 2007-ben, ettól az évtôl már nem főiskolai karként, hanem a Debreceni Egyetem Egészségügyi Karaként múködik.

Az Egészségügyi Szervező Alapszak keretén belül a kar sikeresen akkreditáltatott egy új szakirányt, az egészségturizmus-szervező szakirányt.

A mesterszakok indításával párhuzamosan a kar több szakirányú továbbképzési szak programját is kidolgozta, mind az egészségtudomány, mind a társadalomtudományok területén, s amelyeket folyamatosan indított 2008 óta.

A továbbképzések szervezése, tágabb értelemben a felnôttképzés, egyre fontosabbá vált a kar életében az elmúlt évtizedben. 2001-ben alapította meg az intézmény a Szociális Szakvizsga, Szak-és Továbbképzési Központot, melynek elsődleges feladata az ekkor országosan bevezetett szociális szakvizsga megszervezése és lebonyolítása. A szakvizsgáztatás jogát a kar pályázat útján nyerte el az akkori Szociális és Családügyi Minisztériumtól, az indulást követően pedig eddig már két alkalommal is sikeresen akkreditáltatta. Országosan is egyedülálló, hogy a kar minden szakterületen elnyerte a szakvizsgáztatás jogát. A szakvizsgák fó témacsoportjai a következôk: családvédelem és családgondozás, gyermekjóléti alapellátás, gyermekvédelmi szakellátás, idôsek szociális ellátása, pszichiátriai és szenvedélybetegek szociális ellátása, fogyatékosok szociális ellátása, rehabilitációja, hajléktalan ellátás. A szakvizsgák mellett a központ számos továbbképzési programot is sikeresen akkreditáltatott az elmúlt években. A sikert jelzi, hogy 2001 óta 1138 fó tett szakvizsgát a központ szervezésében.

A központ munkáját a kezdetektől fogva Dr. Horváth László fốiskolai docens irányítja.

Hasonló céllal alapította meg a kar a közelmúltban a Regionális Egészségügyi Továbbképzô Központot, melynek célja, hogy szakmai továbbképzéséket szervezzen a régió egészségügyi szakdolgozói számára. A központ vezetője Dr. Kósa Zsigmond fốiskolai tanár. 
A képzési programok bővülésével és a hallgatói létszám emelkedésével (a kar hallgatói létszáma 2006-ban meghaladta a 3200 foót) egyre fontosabbá vált a karon is a minôségbiztosítás kérdése.

A kari folyamatok, fejlesztések minőségének biztosítására a kar 2006-ban vezette be az EN ISO 9001:2000 szabványon alapuló minőségirányítási rendszert (jelenleg MSZ EN ISO 9001:2008). Az intézményben természetesen korábban is létezett minőségbiztosítási rendszer (EFQM), a vezetés döntése értelmében a kari minőségügyi feladatokat az EFQM kari kiválósági modell és az ebbe integrált MSZ EN ISO 9001:2008 szabvány szerinti minőségirányítási rendszer folyamatos fejlesztésével oldja meg. A kar minôségirányítási rendszere folyamatleírásokkal szabályozza a mûködés minden területét (oktatás, kutatás, gazdálkodás, munkatársi és hallgatói elégedettség), az elmúlt időszakban pedig számos sikeres belsô és külsô auditon ment keresztül.

Az ISO minőségirányítási rendszer keretében 2006 óta számos felmérés készült, a hallgatói elégedettség, a hallgatói motiváció, az egyes kurzusok, oktatók hallgatói véleményezése, intézményi nagygyakorlati, munkatársi elégedettség, munkaerôpiaci, végzett hallgatók pályakövetése, a menedzsment múködésének megítélése, illetve kari önértékelés témakörökben. A felmérések rendszeresek, a kapott információkat kari testületek értékelik, a problémák megoldására pedig különbözô intézkedési tervek kidolgozására kerül sor.

A kari minôségbiztosítás, minőségfejlesztés legmagasabb szintü testülete a Kari Tanács állandó bizottságaként múködő kari Minőségfejlesztési Bizottság. Az operatív feladatokat a Minôségirányítási Csoport (MICS) tagjai, illetve az egyes szervezeti egységekben múködő minőségkörök tagjai látják el.

A kari múködés és az eredményesség értékelésében kiemelt jelentőséggel bírnak azok az indikátorok, amelyeket évente egyértelmúen definiált mutatókkal mérünk. A kari szinten 2006 óta figyelemmel kísért indikátor száma évente 45-50 között mozog. A minőségbiztosítási rendszer irányítását a kezdetektől Dr. Zagyi Bertalan fôiskolai docens végzi.

A képzési paletta bôvülése a hallgatói létszám jelentős növekedését eredményezte, az évtized elsó felében a karnak már közel 3000 hallgatója volt. Több szak esetében a kar a város legkülönbözôbb pontjain bérelt termeket, mivel a rendelkezésre álló infrastruktúra már nem tudta kiszolgálni a nagy létszámú hallgatói csoportokat. Az infrastruktúra bôvítése elodázhatatlanná vált, a terveket és elképzeléseket pedig siker koronázta.

Átadásra került az 500 fố befogadására is alkalmas Zilahi-terem (névadója, Dr. Zilahi József a megyei közgyúlés korábbi elnökeként számos esetben támogatta az intézmény fejlesztési elképzeléseit, ezért is őrzi nevét a kar egyik legújabb és talán egyik legreprezentatívabb terme). A terem multifunkcionális, alkalmas elôadások megtartására, nagyobb konferenciák, bálok, ünnepségek megrendezésére.

Pályázati támogatással felépült a „Torony-épület”, több, a legkorszerúbb eszközökkel felszerelt előadóteremmel és egy számítástechnikai szaktanteremmel. A kar szempontjából „új” épületbe költözhetett a dékáni hivatal, a tanulmányi osztály, va- 
lamint a gazdasági-adminisztrációs egység is, hiszen a megyei vezetés átadta a kar szomszédságában lévő, korábban görög katolikus püspöki palotának szánt épületet, amely az átadást megelőzően a Gyermek-és Ifjúságvédelmi Intézet központja volt. Napjainkra kialakult tehát az a vélhetóen végleges épületegyüttes, amely egyfajta korszerú és minden igényt kielégítô „mini-campus” formájában várja az oktatókat és hallgatókat. Az infrastruktúra biztosítását az alapító okiratban vállaló SzabolcsSzatmár-Bereg Megyei Önkormányzat erején felül eleget tett ígéretének, messzemenốen biztosította a „folyamat jelleggel” történô fejlesztés lehetôségét 20 éven át. Köszönet azoknak (Gyúró Imre, Zilahi József, Pataki József, Gazda László) akik élen jártak a program megvalósításában.

Az egyre bôvülő képzési és továbbképzési profil szükségessé tette a belsô struktúra átalakítását is, amelyre a 2010/11-es tanévben került sor. Átalakításra kerültek a tanszékek, illetve létrejött két nagyobb szervezeti egység, az Egészségtudományi, valamint a Szociális- és Társadalomtudományi Intézet, melyek várhatóan még hatékonyabban tudják majd a képzésekkel és kutatással kapcsolatos szakmai és oktatásszervezési feladatokat koordinálni. Az Egészségtudományi Intézethez négy, míg a Szociális- és Társadalomtudományi Intézethez két tanszék került besorolásra. (4. táblázat)

Az eredmények hátterében a minőségi fejlesztésre koncentráló stratégia áll, amelyet a kar az Orvos-és Egészségtudományi Centrum vezetésével, illetve a centrumhoz tartozó többi kar dékánjaival közösen dolgozott ki még 2008-ban. A hosszabb távú stratégiát a centrum tanácsa, illetve a Debreceni Egyetem szenátusa is elfogadta egy képzésfejlesztési terv formájában.

A stratégia részét képezte az is, hogy az addig debreceni helyszínnel múködô képzések átkerülnek a centrum más karaihoz, így a gyógytornász szak a döntést követôen a Népegészségügyi Kar, míg az Orvosdiagnosztikai Laboratóriumi Analitikus képzés az Âltalános Orvostudományi Kar keretein belül múködik tovább.

4. táblázat: A Debreceni Egyetem Egészségügyi Karának 2010-ben létrehozott új tanszéki struktúrája és tanszékvezetôi.

\begin{tabular}{|l|l|}
\hline Egészségügyi Informatikai Tanszék & Dr. Ködmön József \\
\hline Elméleti Egészségtudományi Tanszék & Dr. Lórincz István \\
\hline Klinikai Egészségtudományi Tanszék & Dr. Kalapos István \\
\hline Pszichológiai Tanszék & Dr. Kiss János \\
\hline Társadalomtudományi Tanszék & Dr. Fábián Gergely \\
\hline Védőnői Módszertani és Népegészségtani Tanszék & Dr. Kósa Zsigmond \\
\hline
\end{tabular}




\section{Nemzetközi kapcsolatok, tudományos- és kutatómunka}

Az alapítás óta a kar számára a nemzetközi kapcsolatok természetesek, sót jelentősen bôvültek az utóbbi években. A kar jelenleg 40 nemzetközi bilaterális együttmúködési szerződéssel rendelkezik, elsôsorban európai országok felsôoktatási intézményeivel, de több amerikai egyetemmel is igen szoros kapcsolat alakult ki, mind az oktatás, mind a tudományos munka területén.

Mivel a kar már alapítását követően 4 olyan képzést indított hazánkban, melyek teljesen újak voltak, nem rendelkeztek előzményekkel, hagyományokkal, a külföldi szakmai segítség természetes volt a képzési programok kidolgozásában. Ez utóbbi különösen intenzív volt a rendszerváltást követô években. Így indult a szociális munkások képzése, de hasonló volt a helyzet az Egészségügyi Ügyvitelszervező Szak esetében is, melyre így emlékeznek vissza az alapítók, Dr. Szegedi János és Dr. Zagyi Bertalan, korábbi szakigazgatók:

„A mit tanitsunk? kérdésre induláskor nemleges válaszaink voltak, azaz azt tudtuk, hogy mit nem akarunk. Nem akartunk sem programozókat, sem adatrögzítóket, sem alulképzett orvosokat, közgazdászokat, egyáltalán olyan szakembereket képezni, akiknek a képzése más felsófokú intézményben már bejáratottan folyik. Azt tudtuk, hogy az egészségügy, az informatika, a közgazdaságtan, a management határait egyaránt érintô területre gyakorlati szakembereket képezni csak profi képzéssel lehet ... Ezt szem elótt tartva a „mit?” kérdésre adott elsố igenlố válaszaink a Chicagoi Állami Egyetem (UIC) és az AMRA (American Medical Record Association) tananyagának áttanulmányozása, illetve a szakembereivel folytatott konzultációk után születtek".

Ezzel párhuzamosan a képzési program összeállításához az alapítók szoros kapcsolatokat alakítottak ki számos európai egyetemmel is, így mintául szolgáltak a bristoli, a glasgow-i, a hannoveri és az ulmi egyetemek tantervei. A legszorosabb kapcsolat azután az amszterdami HvA (Hogeschool van Amsterdam) intézményével alakult ki, melynek oktatói nemcsak a curriculum fejlesztésében vettek részt, hanem rendszeres oktatói is voltak a képzésnek.

Hasonló indítás jellemezte a (akkori nevén) Diplomás Ápoló Szakot is, hiszen már 1991-ben szakmapolitikai döntés született arról, hogy nemzetközi és az Európai Unió normáinak megfelelő ápolóképzés kerüljön kialakításra Magyarországon is. A tanterv kidolgozását, illetve az oktatók felkészítését a Project HOPE Nemzetközi Egészségügyi Oktatási Alapítvány vállalta fel, így alakult ki igen szoros kapcsolat a clevelandi székhelyú Case-Western Reserve University-vel, az East-London University-vel és a finnországi College of Raiumo-val. Az illetékes minisztérium részérôl Dr. Csontos András koordinálta a feladatokat, aki késóbb oktatási helyettesként, majd dékáni tanácsadóként is segítette a kar képzéseinek fejlesztését.

Az ápoló szak az elmúlt évtizedekben tovább bơvítette nemzetközi kapcsolatrendszerét, mára számos amerikai, kanadai és európai felsôoktatási intézménnyel tart fent szoros kapcsolatokat, a kutatás, az oktatás és a tantervfejlesztés területén. 
A szak több nemzetközi szervezet tagja, ilyen pl. az ENNE (The European Network of Nursing in Higher Education), amely rendszeres nemzetközi programokat, továbbképzéseket is szervez ún. Intenzív Programok formájában. Egyik legutóbbi programjuknak, 2011. májusában éppen a kar volt a szervezóje és házigazdája.

A szak az egyik alapítója az ETNA (European Transcultural Nursing Association) nevû nemzetközi szervezetnek, amely 2006-ban Nyíregyházán tartotta nyári egyetemét. A nemzetközi kapcsolatok fejlődésének egy újabb állomása volt 2010, amikor is a szak oktatóinak kezdeményezésére a karon került megalapításra a Sigma Theta Tau International-Honor Society of Nursing magyarországi tagszervezete. Az STTI eredetileg az Egyesült Államok legnagyobb ápolószervezete volt, napjainkra azonban már kilépett a nemzetközi színtérre is. A szervezet 1922-ben alakult meg az Indiana Egyetemen, nevük a görög ABC betúiból tevődik össze (??? - Storgé = Szeretet, Tharsos = Bátorság, Timé = Tisztelet). 1936-ban a világon elôször finanszírozott ápolástudományi kutatást. A nemzetközi színtérre 1985-ben lépett ki, azóta 86 országban van jelen, 469 tagszervezettel, 405.000 taggal. A szervezetnek saját könyvkiadója és 4 szakmai folyóirata van, ingyenesen kereshetô elektronikus adatbázisában 34.000 ápoláskutatási publikáció található, évente átlagosan 500.000 dollárt költ ápoláskutatási programok finanszírozására.

A szervezet európai elnöksége a hazai tagozat megalapítása alkalmából a karon tartotta éves fórumát és közgyúlését 2010-ben.

A szak kiterjedt kapcsolatrendszerének, számos Erasmus-Socrates bilaterális megállapodásának köszönhetôen rendszeresen fogad külföldi vendégoktatókat és hallgatókat, és küld oktatókat, hallgatókat külföldre. Résztvevői voltak, és napjainkban is résztvevôi számos Erasmus-Socrates Intenzív Programnak is (pl. „Clinical Pathway”, „Health Care and Nursing in Europe”), alapítói egy nemzetközi ápolástudományi vándorkonferenciának, melynek a kar 2010-ben volt a szervezóje és házigazdája. A szak 2006-ban Fulbright ösztöndíjas vendégoktatót is fogadhatott, Prof. Dr. Beth Furlong személyében, aki az Omaha University Nursing Faculty oktatója.

A nemzetközi kapcsolatok ,ápolásában” különösen a szak két oktatója, Dr. Papp Katalin és Újváriné Dr. Siket Adrienn szereztek elévülhetetlen érdemeket.

A számos partnerkapcsolatból érdemes kiemelni a csehországi University of South Bohemia (Ceske Budejovice) intézményével kialakított igen intenzív, és sokrétú együttmúködést, hiszen ez a szak egyik olyan kapcsolata, amely az oktatástól, a tantervfejlesztésen át a közös kutatási programokig a teljes palettát magába foglalja.

Prof. Dr. Valéria Tóthova, az egyetem Egészségügyi és Szociális Karának dékánja így emlékezett vissza a kezdetekre, és a kapcsolatok folyamatos bóvülésére:

„Tiz évvel ezelótt Budapesten, egy nemzetközi konferencián találkoztam elôször Papp Katalinnal. A megismerkedésünk után bemutatta nekem Dr. Lukácskó Zsoltot, az akkori dékánt. Rövid bemutatkozásom után arra tereltem a szót, hogyan lehetne együttmüködni az ápolóképzés terén. Erre a kérdésre adott válasza még ma is a fülemben cseng: éppen egy neves szakemberrel találkoztam, aki Nyíregyházán 
az ápolóképzésben jelentôs szerepet tölt be.

Az elsố utam Ceske Budejoviceról Nyíregyházára már az elkövetkezô év áprilisában megvalósult, amikor a Diplomás Ápolók Konferenciáján egy elóadással vettem részt. Akkoriban Csehországban még csak tervezgettük az ápolóképzés átalakitását, amely keretén belül a föiskolai és egyetemi képzés megvalósítására törekedtünk.

Késóbbi találkozásunkkor már egy éve létezett az Egészségügyi Szociális Karunkon az ápolók egyetemi képzése. Visszatérve a 2001 évre, Papp Katalinnal és a többi magyar kollégával nagyon sokat beszélgettünk a cseh, és a magyar ápolásról. Rövid idôn belül újból Nyíregyházára utaztam, de már nem egyedül, hanem a Karunk dékánjával és így megindultak a hivatalos tárgyalások is. A két dékán megbeszélését a két egyetem együttmúködési szerződésének az aláirása követte.

A hivatalos tárgyalásokon kívül részletesen megismerkedtünk az egyetem történetével, meglátogattuk a Megyei Kórházat és más egészségügyi intézetet, ahol a kar hallgatói a szakmai gyakorlatukat végzik. A Délcsehországi Egyetem rektora és a kar korábbi dékánja a mai napig emlegetik, hogy olyan csodálatos, kedves és nagylelkú emberekkel, mint Nyíregyházán, még nem találkoztak.

A szerződés aláirásával megkezdödött az a csereprogram, amely mind a mai napig évról évre sikeresen realizálódik - cseh hallgatók érkeznek Nyíregyházára és magyar hallgatók Ceske Budejovicere. Hallgatóink megismerkednek az egészségügyi rendszer jellegzetességeivel, s az ápolás területén megbizott szakemberek avatják be a magyar ápolás titkaiba. Szívesen emlékeznek vissza az itt töltött napokra, s ha lehetôségük lenne rá, örömmel visszatérnének Nyíregyházára.

Nemcsak hallgatók utaznak Nyíregyházára, hanem magam is minden évben meglátogatom az Egészségügyi Kart - az ápolási tanszék szakembereivel dolgozunk együtt. Természetesen, kolléganóim is aktív részesei ennek az együttmüködésnek. Bekapcsolódunk az elóadásokba és közös publikációink jelennek meg. Az együttmúködésünk nemcsak a kétoldali egyetemi szerzôdés alapján történik, hanem az Erasmus-programon belül is. A nyíregyházi kollégák szintén részt vesznek a Karunk által szervezett programokban.

A nemzetközi együttmúködéseknek, csereprogramoknak nagy jelentôségük van, mert gazdagítja ismereteinket, tudásunkat. Nemcsak az Európai Unióba való tartozásunk, hanem a globalizációs folyamatok is megkövetelik, hogy megismerjük egymást, közösen fejlesszük szakunkat és átadjuk pedagógiai ismereteinket, kutatási eredményeinket egymásnak. Megtiszteltetés részemre, hogy együtt dolgozhatok a nyíregyházi kollégákkal, s kívánom, hogy további sikereket érjenek el az oktatás és a tudományos kutatómunka területén. Eddigi elért eredményeik tanúsítják, hogy minden szakon kiváló szakemberek dolgoznak, s ez a garancia arra, hogy az elkövetkezó évtizedekben a Debreceni Egyetem Egészségügyi Kara eleget fog tudni tenni a rohamos fejlódés új kihívásainak".

Hasonló indulás jellemezte az Általános Szociális Munkás Szakot, ahol a külföldi kapcsolatok viszonylag hamar közös, nemzetközi kutatócsoportok kialakulásához vezettek. 1993 óta létezik a LOSS (Local Organisation of Social Security) összehasonlító kutatási program, amely német kollégák kezdeményezésére jött létre, a 
kar pedig német és angol egyetemek mellett az alapítók közé tartozik. A vizsgálatban hazánkat a kar, és az MTA Politikai Tudományok Intézete képviseli, mellyel 2004-ben együttmúködési megállapodást is kötöttünk a szociálpolitikai és egészségpolitikai közös kutatási programok lebonyolítása érdekében. Változó formában, változó témakörökkel ugyan, de a LOSS program napjainkban is múködik, idôközben csatlakoztak hozzá amerikai, finn, és olasz intézmények is. Az egyik elsố belépố partner a finnországi Oulu egyeteme volt, amelyet Prof. Hannu Pietiläinen és Aira Vanhala képviselt a kutatócsoportban, a bilaterális kapcsolatok azonban rövid idô alatt kiszélesedtek, ahogyan erról Hannu Pietiläinen egyik interjújában is megemlékezett:

„1993-ban voltam olyan szerencsés, hogy elôször látogathattam Nyíregyházára. Már tudtam valamennyit Magyarországról, mivel tíz évvel ezelótt néhányszor megfordultam az országban. De 1993 végén hivatalos kapcsolat kezdödött a két egyetem között. Azóta számtalan alkalommal látogathattam el Magyarországra, ahol nagyon sok jó kollégám és barátom van. Az együttmúködés a kezdetekben a hallgatói, illetve tanár-cserét jelentette, amely 1994 májusában kezdódött, amikor két magyar diák érkezett Finnországba. Még emlékszem arra a napra, amikor a diákok, Kati és Laci (Szoboszlai Katalin és Patyán László) megérkezett Ouluba. Május elseje a tavasz karneválja Finnországban. A városban mindenhol jókedvú diákokat és embereket láthattunk, akik mulatságos ruhákat viseltek, gyerekek lufikkal, a felnóttek pedig boroztak, söröztek. Májusban nálunk 24 órás világosság van, mert a nap késôn nyugszik és nagyon korán kel. Ez problémát jelenthet, ha valaki nincs hozzászokva az esti napfényhez. Lacinak elég nagy gondot okozott az éjszakai alvás a szokatlan világosság miatt, ezért egy fekete sötétitót rakattunk a szobája ablakára, ami segitett. Katinak szintén emlékezetes lehet az a finnországi látogatás, mivel balesetet szenvedett a Kuusamo-i vadonban. Egy gyalogtúrát tettünk a keleti határ közelében és megsérült a lába, a gyaloglás komoly gondot okozott számára. Ezért 4 órát töltöttünk a Kemijarvi-i egészségközpontban, Lapföld északi részén és munka közben figyelhettük meg, hogyan is müködik az egészségügyi szolgáltatás. Ez volt az, amit úgy hivhattunk, hogy a tapasztalati tanulás folyamata.

A jó kezdés után, majdnem minden évben tudtunk diákokat és tanárokat fogadni és küldeni a csereprogram keretében. De más tevékenységekben is részt vettünk közösen, Németországgal és Olaszországgal felváltva, különbözô helyszíneken rendeztünk meg például egy európai Intenzívprogramot. Az egyik legfontosabb kapcsolat a LOSS csoport, amelyben évente szervezünk nemzetközi konferenciákat néhány európai országban és az Egyesült Államokban is. A szociális szolgáltatások és a különféle szakmai újdonságok iránti közös érdeklôdés a sarkalatos pontjai ennek a nemzetközi hálózatnak. Természetesen sokat tanultunk a szolgáltatási rendszerekról és a szolgáltatások átadásáról ezen évek alatt, de szintén széles körben tájékozódtunk arról, hogy mi is folyik Európában és Észak-Amerikában. Szintén a LOSS témái közé tartoznak a társadalmak jelenlegi változásai, például az idôsödés kérdései, az alkohol és drogproblémák, a nemzetközi vándorlás és regionális változások.

Nemzetközi programjainkban az egyik legfontosabb kapcsolatunk a szociális mun- 
ka oktatásában való együttmúködés Nyíregyházával. A szociális munkához társult az ápolás, a sürgôsségi ellátás, és a fizikoterápia”.

A LOSS programból az elmúlt években számos hazai és nemzetközi publikáció, kiadvány született, a kutatócsoport tagjai rendszeresen szerveznek konferenciákat, a kar eddig három alkalommal volt házigazdája a csoport éves ülésének. A házigazda szerep pedig újabb kapcsolatot is eredményezett, ezúttal az amerikai Louisville-i Egyetemmel, melynek képviselője Prof. Dr. Thomas R. Lawson mára szinte a kar „főállású dolgozójává” vált, olyan intenzív kapcsolattá fejlődött a kezdetekkor a kutatási programra vonatkozó együttmúködés. Egyik nyíregyházi látogatásakor adott interjújában így emlékezett vissza erre az időszakra Lawson professzor:

„Elôször 1995-ben találkoztam Fábián Gergellyel az egyik elsô LOSS konferencián Birminghamben, Angliában. Ezt követóen Olaszországban, Finnországban és az Egyesült Államokban voltak közös konferenciáink. Amikor Magyarországra érkeztem a LOSS konferenciára, felismertem, hogy milyen csodálatos hely is ez a melegségével, nyiltságával és a nyíregyházi emberek barátságosságával. Olyan helynek tartottam a föiskolai kart, ahol elkötelezettek a diákok magas színvonalú oktatása iránt, jelentös szerepet játszanak a helyi közösségben, valamint a társadalomban pontosan úgy, ahogy ezt egy föiskolának tennie kell.

Emiatt azonnal egy csereprogramot kezdtem el tervezni az egyetemem és az egészségügyi kar között Dr. Lukácskó Zsolttal, Dr. Horváth Lászlóval és Gergellyel. Elöször 1999-ben hoztam diákokat Nyíregyházára. Nagyon jól emlékszem az elóadásokra, amelyeket a hallgatóimnak tartottak a karon, a START Vállalat meglátogatására Balogh Zoltánnal, a Guszevi általános iskola meglátogatására Patyán László vezetésével, a Debreceni Egyetem, valamint a Csapókerti Közösségi Ház meglátogatására Debrecenben Giczey Péterrel, és természetesen a fantasztikus ételekre melyet a csoportunk számára biztosítottak.

Az elsố látogatásom óta a csereprogram egyre növekedett és egyre sokszinúbbé vált. Minden második évben (2001-ben, 2003-ban, 2005-ben, 2007-ben, 2009-ben, és 2011-ben) vittem diákokat a föiskolára azért, hogy tapasztalatot szerezzenek az ösztönzố elôadásokból, a különbözố új intézmények, szociális szolgáltatók meglátogatásával, de például a START, a Periféria mindig az állandó programjaink közé tartozott.

Továbbá sikerült betekintést nyerni Nyíregyháza és környéke kulturális életébe is. Meghallgattuk a Banchieri, valamint a Pro Musica kórust, megnéztünk helyi néptánc programokat, és ellátogattunk Tokajba, ahol vacsoráztunk és megkóstoltuk a borokat egy helyi borospincében - mindezt a kar valamint a helyi tanárok szervezésében -, melyek fontos mozzanatai voltak minden látogatásunknak.

Amikor külföldre utazunk a diákjaim mindig aggódnak az étkezés miatt, de ök rajongva beszéltek azokról az ételekról, amelyeket a menzán, a START Vállalatnál, vagy a helyi éttermekben fogyasztottak a programok alatt és azt kívánják, bárcsak ilyeneket ehetnének Louisville-ben. Minden diákom azt mondja, hogy a föiskolai karral való csereprogram a legjobb, ami létezik és a legfontosabb ok, az ott élô em- 
berek! Mindig azt mondják nekem, hogy a legcsodálatosabb emberek ott vannak Nyíregyházán.

Nemcsak diákok voltak a csereprogram keretében Nyíregyházán, mivel az egyre tartalmasabb program sokkal több mindent foglal mára magába. Néhány kolléga a karról ellátogatott Louisville-be 2000-ben és 2007-ben, valamint közösen rendeztük meg a Szociális munka az egészségügyben címú amerikai - magyar konferenciát. A konferencia anyaga a napokban jelent meg könyv formájában, a két intézmény közös kiadásában. 2009 öszén Dr. Anna Faul - elismert gerontológiai szakértôje a louisville-i egyetemnek - látogatott Nyíregyházára egy konferenciára, elôadásokat tartott a hallgatóknak, és ez az együttmüködés még folytatódni fog.

Mi is ennek a nagyszerú csereprogramnak a titka? Maguk az emberek! Azok az emberek, akik együtt dolgoznak, akik barátok - kollégák és elkötelezettek aziránt, hogy a legjobb oktatást biztosítsák a diákoknak, legyenek azok Amerikában, vagy Magyarországon. A közös programok, melyek elkötelezetté teszik a diákokat arra, hogy egy globális társadalomban tanuljanak és dolgozzanak, akadémikusok, akik kutatásokat vezetnek azért, hogy javitsák, segitsék az emberek életét, nem foglalkozva azzal, hogy hol élnek, a diákok, akik együtt tanulnak és dolgoznak határokon túl azért, hogy gyarapítsák tudásukat és javitsák képességeiket".

A csereprogram folyamatosan bővült, a Nyíregyházán járt amerikai mesterszakos, illetve PhD hallgatók közül többen szintén a kar „munkatársai” lettek, az együttmúködés pedig azóta is folyamatos. Dr. Steve Drewry, aki a kétezres évek közepén még PhD hallgatóként járt Nyíregyházán, s aki mára már az ohio-i Capital University vezetô oktatója, egy újabb bilaterális kapcsolat képviselője, így írt első látogatásának élményeirôl:

„A budapesti Keleti-pályaudvar lassan eltünt mögöttem és elhelyezkedtem az ülésemben a hosszú útra Nyíregyházáig. Az Egyesült Államokból Amszterdamig tartó repülôút nagyon fárasztó volt, de ezután egy rövid járattal a magyar MALÉV-val megérkeztem a Ferihegyi repülótérre. Az út kellemes volt, jól éreztem magam, mivel a barátságos légikisérók kitünó magyar ételeket szolgáltak fel. Mindig ideges vagyok a repüléstól, és úgy éreztem magam, mint aki napok óta nem aludt.

A vonat keresztül gördült Budapest külvárosain, fokozatosan haladtunk a városból kifelé, az épületek egyre kevésbé voltak ipari jellegúek, sokkal inkább emberek által lakottak, mig fokozatosan bele nem simultak az Alföld nyugati szélébe.

A vonat lágyan rázkódott a vágányokon, sebességét lassan fokozva hozzászoktam a vonat ritmusához, mely végül elringatott engem, egy hosszú, megérdemelt álomba.

A kimerültség miatt nem aludtam sokat, izgatott voltam. Hosszú ideig bámultam ki az ablakon, néztem az elsuhanó tájat. A vonat mérföldeken keresztezte a végeérhetetlen üres, havas mezóket, újra és újra falvakkal megszakitva, melyek a sinekhez közel terültek el. A házakat összeépitették, mintha a szél zordsága miatt bújtak volna össze; barnák, mállottak és idótlenek voltak. A falvakból sáros nyomok vezettek az utakra, autók oly ritkán és szükségtelenül látszottak rajtuk.

Egyszerú fasor szegélyezte a horizontot a távolban, mely tisztábbá vált, amint a nap ereszkedett és az alkonyat leszállt. Láttam, amint a rókák versenyeznek nyu- 
lakat kergetve az üres mezôn, azonban a vonat túl gyorsan haladt, hogy láthassam mi lett a vége. Késóbb láttam egy kis ózet, amint a hóval fedett tarlót kutatta ételért. Az ismerös állatok látványa felvidított, a vidéket kevésbé idegenné tette. A föld nagyon sötét volt és kemény, csakúgy, mint nálunk Ohio-ban, tökéletes kukoricatermesztésre, de furcsán örizetlen.

Egy másik faluban, éppolyan mint az elózô, halvány fények pislákoltak az ablakokban, füst gomolygott a kéményekból a sötétségbe, és szállt tova. Idôvel egy város tünt fel hatalmas arc nélküli épületeivel, melyek hirtelen emelkedtek ki a síkságból, praktikus lakásokkal az öreg proletároknak, melyeket jóval a rendszerváltás elótt épitettek, de valahogy fennmaradtak.

Ezek utat engednek az otthonokhoz; ragyogó sárgára, kékre és fakó zöldre festettek, melyek a szocializmus és a terror elótti életre emlékeztetnek, mely mostanra helyreállt és felélénkült a jobb jövó felé tekintve. A fények melegen pislákolnak az ablakokban. Emberek vannak az üzletekben és az utcákon. A vonat lassan megállt az állomáson. Levonszoltam csomagjaimat a vonatról, az aluljárón felmentem az állomásra és elöször pillantottam meg Nyíregyházát. Valahogy egyáltalán nem éreztem idegennek.

Magyar kollégáim, Patyán László és Fábián Gergely üdvözöltek, akikrôl sokat hallottam, de akikkel sohasem találkoztam. A mosolyuk azt mondta, hogy jó kezekben leszek. Együtt utaztunk a Hotel Centrálba, ahol megszálltam, miközben beszélgettünk az utazásomról és ismerkedtünk egy kicsit. Nagyon szivélyesek voltak hozzám. Minden kezdeti bizonytalanságom tovaszállt. Az elkövetkezendó néhány hétben számos magyar kollégával találkoztam, akikkel hamarosan barátok lettünk. Bay Ilona tolmácsolt, könnyen megértettük egymást, mesélt egy nyakláncról, melynek a medálja egy John F. Kennedy ezüst fél dolláros volt és arról, mennyire szerette azt.

Felfedeztem, hogy Lacinak és nekem ugyanúgy szenvedélyünk a sporthorgászat, és azt, hogy Gergely, csakúgy mint én, imádja a chicagói blueszenét. Lacival horgász sztorikat osztottunk meg egymással etetésról, csalikról és nagy csukák fogásáról. Hiszem, hogy két horgászember a valót mondja egymásnak, ami elmúlt. Gergely és én örömmel osztottuk meg a blues iránti szeretetünket. Muddy Waters, Buddy Guy, Junior Wells, Eric Clapton és elöször hallottam Deák Bill Gyula 'Bort, Bluest, Békességet!' dalát.

Természetesen dolgoztam is. Nagyon sokat tanultam a magyar szociális munkáról és a magyar történelemröl, de legfóképpen a magyar emberekról és valamit önmagamról. Keresztül utaztam az Egyesült Államokat, éltem Középnyugat-Amerikában, Chicago-ban, Kaliforniában, Oregonban, jártam Alaszkában, Kanadában és rengeteg csodálatos emberrel találkoztam. De igazán sehol sem találkoztam olyan nyitott, kedves és nagylelkü emberekkel, mint itt Nyíregyházán.

Az elsó látogatás óta számos projekten dolgoztam együtt a Debreceni Egyetem Egészségügyi Karának oktatóival. Együttmüködtünk az MSc képzés tantervének kidolgozásán, etikai kutatásban, és az egészségügyi szociális munkában is.

Megtisztelve érzem magam, hogy kis mértékben hozzájárulhattam a föiskola (a 
Kar) sikeréhez, de ami a legértékesebb számomra az a barátság, amelyet ápolok a kedves és becses kollégáimmal. Segítettetek kinyitni a szememet egy új világra, amely felülmúlta eddigi tudásomat és tapasztalataimat, és gazdagitottátok életemet a jelenlétetekkel".

A nemzetközi kapcsolatok bôvülése tette lehetôvé, hogy a kar az elmúlt öt évben, a tavaszi időszakban rendszeresen megrendezhette az ún. Nemzetközi Oktatói Hetet, melynek során külföldi vendégoktatók tartottak előadásokat a hallgatóknak, mind társadalomtudományi, mind egészségtudományi, gyakorta mindkét területet érintő, interdiszciplináris témakörökben.

A kurzusok sajátsága volt, hogy azokon minden szak hallgatói részt vehettek, a követelmények teljesítése után pedig kreditpontot szerezhettek. A nemzetközi hetet nemcsak előadások, hanem kifejezetten gyakorlatorientált szemináriumok is jellemezték. Az elmúlt időszakban cseh, szlovák, lengyel, román, német, osztrák, francia, svájci, finn, török, bolgár és amerikai vendégprofesszorok kurzusain vehettek részt a hallgatók.

Egyikük, Prof. Dr. Ellen L. Csikai, az alabamai egyetem professzora, aki 2008-ban Fulbright ösztöndíjasként oktatott a karon, így emlékezett vissza a kapcsolatfelvétel időszakára:

„Egy Fulbright ösztöndíj keretében nyílt lehetôségem arra, hogy megismerjem az Egészségügyi Kart, 2008 januárjától júniusig. Amikor elhatároztam, hogy jelentkezek a Fulbright ösztöndij programjára az elsố és egyetlen gondolatom az volt, hogy Magyarországra menjek. Mindezt azért, mivel tudtam, hogy a szociális munka területén szerezett tapasztalatom, oktatói szaktudásom, valamint az egészségi állapotra, a haldoklásra, a hospice-ra és a palliatív gondozásra vonatkozó kutatásaim egyre nagyobb érdeklödést keltenek és egyre fontosabbak Magyarországon (és Közép-, valamint Kelet-Európa más részein). De más okom is volt, hogy a Magyarországon való tanítást választottam. Nagyapám Tiszaladányban született, Magyarországon (édesapám oldalán mindkét nagyszüloom magyar származású). Úgy éreztem, kapcsolatban vagyok a magyar emberekkel és jobban meg akartam ismerni a származásomat.

Szerencsés voltam, hogy már a pályázatom során kapcsolatot alakithattam ki az Egészségügyi Karral. A Kar tapasztalt szakembert akart hozni a Szociális Munka Alapszakra különösen azért, mert az Egészségügyi Szociális Munka Mesterképzés fejlesztéséról volt szó, melyet akkor kínáltak elöször a hallgatóknak.

Mindketten azonnal láttuk, hogy ez a kapcsolat elönyös lehet nekem, mint tanárnak és a karnak, valamint a diákoknak egyaránt. Miután megtudtam, hogy elnyertem a Fulbright ösztöndíjat, értesültem arról, hogy az Egészségügyi Kar néhány tagja az Egyesült Államokba érkezik egy konferenciára. Ekkor az Alabama-i Egyetem dékánjának nagylelkú segítségével sikerült megszerveznem számukra Szociális Munkás Karunk meglátogatását. Meglátogatták az egyetemet, elóadást tartottak a kar oktatóinak és a diákoknak a magyarországi szociális munka oktatásáról, a szociálpolitikáról, valamint az idôsek részére nyújtott szolgáltatásokról. Meglátogattuk a környezố vidék egészségügyi és szociális szolgáltatásait. Ez nagyszerü lehetôség volt 
mindannyiunk számára, hogy megismerjük egymást mielótt Magyarországra érkezek 2008 januárjában.

Érkezésemkor azonnal úgy üdvözöltek, mint egy igazi magyar partnert. A kollégák segítettek beilleszkedni a magyarországi, valamint a fóiskolai (kari) életbe. Kurzusokat tartottam egészségügyi szociális munkából és palliativ gondozásból tolmácsolással és angol nyelven egyaránt. Lehetôségem nyílt arra, hogy elóadást tartsak minden szak, valamint a helyi közösség tagjai számára. Továbbá sok szociális intézményt meglátogattam, ezáltal megérthettem, hogy milyen szolgáltatásokat ajánlanak a rászoruló embereknek, illetve megtudhattam, hogy milyen segítségre lehet szükség ahhoz, hogy emelkedjen a magyarok életminósége, különös tekintettel az egészség területére. A helyi szakemberek szívesen fogadtak és mutatták be szolgáltatásaikat, valamint azt, hogy milyen kihívásokkal kell szembenézniük szolgáltatásaik biztositása során.

A Magyarországon eltöltött idő alatt lehetôségem nyílt arra is, hogy kutassam családom történetét, találkozzak rokonaimmal, akiket látogatásom elótt nem ismertem. Ebben a karon dolgozó kollégáim is segítségemre voltak, mivel ismertek olyan embereket, akik segíteni tudták kutatásomat. El nem tudom mondani mit jelentett ez nekem, különösen az édesapámnak! Ellátogathattunk Tiszaladányba, megnézhettem azt a falut, ahol a nagyapám született és nevelkedett 11 éves koráig és természetesen találkozhattam a még ma is ott éló rokonaimmal. Az újonnan megtalált családom teljesen befogadott és ezért nagyszerú emlékeim vannak róluk.

Nagyon sok emberrel találkoztam a kar révén, akikkel egy életre barátok, kollégák leszünk és remélem, visszatérhetek Magyarországra, valamint a karra még sokszor a jövóben. Örökké hálás leszek a lehetốségért és a kedvességért, amit irántam mutattak".

A kapcsolat az alabamai egyetemmel és Dr. Csikaival azóta is igen intenzív. Kezdeményezésére és segítségével rendezhette meg a kar a pszichoszociális onkológia legjobb gyakorlatai témájú magyar-amerikai közös konferenciát, melyet a Cancercare és a NASW (National Association of Social Workers) támogatott. A szak oktatói és az amerikai partnerek jelenleg egy közös összehasonlító kutatási program megvalósításán dolgoznak.

A LOSS program mellett a kilencvenes évek egyik fontos kutatási programja volt a szociális munkások pályaképének, pályaorientációjának felmérése, amely a nemzetközi kapcsolatokra alapozva, szintén nemzetközi összehasonlításban valósult meg, magyar, olasz, finn, német és amerikai közremúködókkel. A Dr. Fónai Mihály és Dr. Kiss János vezette kutatási program hazai viszonylatban elsóként vizsgálta ezt a témakört, a vizsgálatból pedig számos publikáció, kiadvány született. Ebben az időszakban, többek között az említett kutatásokat is, sikeres OTKA és OKTK pályázatok támogatták a tudományos programok megvalósítását. A LOSS program és a pályakép kutatás mellett OTKA támogatásban részesült Hüse Lajos (Szülók szocioökonómiai státusza és a gyermekek nemi aránya közötti kapcsolat), valamint Horváth Andrea (Kétszemélyes és társadalmi dilemmák alakulása a hétköznapokban) kutatási programja is. Ebben az időszakban azonban nem- 
csak OTKA, hanem több, más sikeres pályázati forrásból (pl. Soros Alapítvány, ETT) finanszírozott kutatási program is zajlott, és már ekkor is jellemzó volt az interdiszciplináris szemléletmód. Jó példa erre az az öt éves kutatási program, amely Szabolcs-Szatmár-Bereg megyében vizsgálta az öngyilkosságokat, s amely a szociális munkás, a diplomás ápoló szakok, valamint az ÁNTSZ munkatársainak együttmúködésében valósult meg a korábbi Múvelődési és Közoktatási Minisztérium, illetve az Egészségügyi Tudományos Tanács támogatásával.

A szociális képzések oktatói is számos Erasmus-Socrates Intenzív Program résztvevôi voltak, több esetben az ápoló szakkal közösen. Az önálló programok közül kiemelkedő fontosságú volt a Street Life elnevezésú, a hajléktalanság különbözô dimenzióival foglalkozó program a kétezres évek második felében. A három éves program érdekessége, hogy az eredményekból két angol nyelvû, nemzetközi tanulmánykötet is született.

A nemzetközi kapcsolatok egyik legfrissebb „terméke” pedig a SOWOSEC (Social Work and Social Economy) elnevezésû mesterszak (MA), amely 9 európai egyetem együttmúködésében valósul, s amely Magyarország első akkreditált joint degree képzése, amely 2011-ben indult a karon.

Az elmúlt évtized során a Gyógytornász szakon is számos kutatási program zajlott, melyek közül kiemelésre méltó a Dr. Rapcsák Mariann vezette „A humán vázizom adaptációja, különös tekintettel az izommúködés szabályozásában résztvevố kontraktilis fehérjék változásaira" elnevezésû program, amely külsô támogatás segítségével valósult meg.

Számos kutatási és fejlesztési program egyetemen belüli kollaborációban valósult meg. Ilyen volt az Ortopédiai Klinika Biomechanikai Laboratóriumával közös projekt, melynek során kifejlesztésre került egy elektromos járósarok, amely az alsóvégtagi tehermentesítés betanítására és kontrolljára szolgál. A program vezetôi Dr. Csernátony Zoltán klinikaigazgató és Pálinkás Judit gyógytornász voltak, a fejlesztés pedig egy sikeres ETT pályázat finanszírozásával valósult meg. Hasonlóan gyümölcsözố együttmúködés alakult ki a DE-OEC Reumatológiai Tanszékével is.

Az Orvosdiagnosztikai laboratóriumi analitikus képzésben már a kezdetektôl kiemelten fontos kutatási terület volt a kataláz enzim múködésére vonatkozó program, melynek irányítója Prof. Dr. Góth László, a Klinikai Kémiai Analitikai tanszék vezetôje volt. A programban a következô foobb területek vizsgálatára került sor: a vér kataláz aktivitásának változása olyan megbetegedésekben, amelyek patomechanizmusában a szabadgyökök, illetve a hidrogénperoxid szerepet játszhat, a kataláz enzim génje mutációinak vizsgálata ezekben a betegségekben, a hazai veleszületett katalázhiány klinikai és biológiai vizsgálata. A tanszék munkatársai számos hazai és nemzetközi közleményben publikálták kutatási eredményeiket, illetve a programhoz kapcsolódik egy magyar szabadalom is (egyszerú eljárás nukleotid polimorfizmusok kimutatására) 2007-ból.

Góth professzor úrnak köszönhetően a szak számos intenzív nemzetközi együttmúködést tudott kialakítani, amelyek közül különösen az amerikai kapcsolatok voltak jelentôsek, azok közül is elsődlegesen a Stanford University-vel, illetve a San 
Francisco State University-vel kialakított kapcsolatrendszer.

Az elmúlt évtized második felében bekövetkezett változások (egyetemi és uniós integráció, Bologna-rendszer bevezetése, a külső feltételrendszer átalakulása, csökkenô források) egyértelmúvé tették, hogy a tudományos munka gyakorlásához egy átfogó, ugyanakkor konkrét elemekból álló stratégia kidolgozására lesz szükség a karon. Az új, támogató rendszer fokozatosan került bevezetésre, ennek fóbb elemei a következők:

A tudományos utánpótlás biztosítása érdekében, egyedi módon, a kar kialakította a doktori tanulmányokat folytató munkatársak támogatási rendszerét, amelyet egy, a Kari Tanács által is elfogadott szabályzat biztosít. A szükséges anyagi forrást a kar saját bevételei biztosítják. Az elsô időszakban a kar létrehozott egy ún. kari tudományos alapot, ez biztosította a doktoranduszok támogatását, az új kari szervezeti struktúra kialakítását követően ezek az összegek az intézetek hatáskörébe kerültek, akik a szabályzatba foglaltak alapján továbbra is támogatják a munkatársakat. A támogatás többek között a tanulmányok végzését (pl. költségtérítési díj kiegészítését, eljárási díjak befizetését), a tanulmányokkal kapcsolatos dologi kiadásokat, belföldi és külföldi konferencia részvételt biztosít.

A doktoranduszok munkáját segíti az a 2007-ból származó kezdeményezés, melynek alapján a Nyíregyháza városában múködô három felsőoktatási intézmény (Nyíregyházi Főiskola, Szent Atanáz Görög Katolikus Hittudományi Főiskola és a kar) megalapította a Nyíregyházi Doktorandusz Konferenciát karunk oktatóinak kezdeményezésére. A konferenciára évente kerül sor, változó helyszínnel, hiszen minden évben valamelyik főiskola ad otthont a rendezvénynek. A doktoranduszok a konferencián előadással és poszterrel is szerepelhetnek, az elhangzott prezentációkból pedig minden évben lektorált tanulmánykötet jelenik meg, amely publikációs lehetôséget biztosít a résztvevóknek.

Hasonló céllal hozta létre a kar a Tudományos Tanácsadó Bizottságot, melynek elsôdleges feladata a kari tudományos élet koordinálása, szervezése, irányítása, a főbb stratégiák kidolgozása. A folyamatosan, magas színvonalon végzett tudományos kutató és oktató munka elismerésére alapította meg a kar saját kitüntetését, a Kövér András emlékérmet. Az emlékérem odaítélésérôl a szervezeti egységek írásos javaslata alapján egy ötfôs kuratórium dönt. Ebben az elismerésben a vizsgált idôszakban eddig 3 oktató részesült. A kitüntetés átadására az adott év novemberében kerül sor, a Magyar Tudomány Ünnepe keretében, nyilvános tudományos előadással egybekötve.

Hasonló elismerést tükröz a Hadházy emlékérem, amely a kimagasló tanulmányi és tudományos eredményeket elért hallgatókat díjazza, s amely minden évben a diplomaosztó ünnepségen kerül átadásra.

Szintén hasonló cél vezérelte a kar vezetését, mikor 2007-ben létrehozott egy tudományos fómunkatársi státuszt, amelyet már az adott évben betöltött egy olyan pályázóval Dr. Semsei Imre személyében, aki MTA doktori fokozattal rendelkezik és jelenleg a kar tudományos dékánhelyettese is egyben. Feladata a tudományos munka segítése, irányítása, szervezése és menedzselése. Dr. Semsei Imre irányítá- 
sával jött létre a kar egyik legújabb oktatási és szervezeti egysége a Gerontológiai Tudományos Koordinációs Központ. A szervezet alapvetô célja a hazai gerontológiai élet koordinálása és szervezése, a hazánkban, de elsősorban a Karon folyó gerontológiai oktatás segítése, a gerontológiai információk terjesztése, feladatai közé tartozik a hazai gerontológiai publikációk összegyújtése és megismertetése, gerontológiai tárgyú konferenciák szervezése a gerontológiai felnőttképzés bevezetése és megvalósítása.

A GTKK sikeres múködését jellemzi, hogy 2011-ben a szervezet felvételt nyert az Európai Unió AGE-Platform szervezetébe, amely egy 165 tagszervezetet tömörítő nemzetközi hálózat, s amelynek célja az időskorúak érdekeinek európai szintú képviselete.

A központ aktivitását jellemzi az az évente megrendezésre kerülő konferencia is, amelyik nemcsak a hazai gerontológia és geriátria jeles képviselőit sorakoztatja fel, hanem napjainkra már nemzetközivé vált.

Szintén a központ gondozásában és kiadásában jelenik meg 2008 óta a Magyar Gerontológia címú hiánypótló folyóirat. Az elsố szám köszöntőjében Dr. Semsei Imre, a folyóirat főszerkesztője így írt a lap céljáról és feladatairól:

„Egy hiánypótló kiadványt indítottunk útjára, hogy fórumot nyújthassunk a hazai gerontológia minden ága képviselöjének. Ugyanúgy helyet kapnak a kisérletes-, és a biogerontológia eredményei, mint a geriátria, és szociális gerontológia müvelöinek írásai is. Emellett tervezzük, hogy a kapcsolódó társdiszciplínák képviselói is lehetôséget kapnak a gerontológiával kapcsolatos eredményeik ismertetésére, hiszen a gerontológia mind eszköztárában, mind pedig tematikailag multidiszciplináris tudományág, s csak a társtudományok haladásával egyidejüleg tud fejlödni. Igaz, hogy számos kiváló nemzetközi gerontológiai és geriátriai folyóirat létezik, de sok olyan kérdés is felmerül, mely hazai diszkussziót kíván, s noha más országok számára is tanulságokkal szolgálhat, elsôsorban mégiscsak a magyar nyelvterület gerontológiai kérdéseit, gondjait, eredményeit hivatott közreadni”.

A folyóirat indulását a következôképpen üdvözölte Vértes László professzor, a Magyar Gerontológiai és Geriátriai Társaság alelnöke:

„Életünkben vannak pillanatok, amikor érdemes megállnunk: viharos világban asylumra lelni, örömöt felfedezni ... Most lapot, új szaklapot köszönünk ... Gerontológusok vagyunk, ki-ki valamelyik ágában munkálkodik, ki több évtizede, ki hónapok óta. A nagy tervek, a nagy álmok között - eddig - a „saját lap”, a mi folyóiratunk, szép területünk, pályánk szaklapja hiányzott. Megvallom, irigykedve vettük kézhez más országokbeli kollégáink kiadványait, immár sokadik évfolyamokat jelzố számokra sóhajtottunk ... a hazai gerontológia egyik legkiemelkedóbb állomásának lehetünk tanúi ... Köszönjük, megbecsüljük, tiszteljük - és éljen jó évszázadokon át."

A kar húszéves jubileuma alkalmából indította útjára újabb tudományos folyóiratát, Acta Medicinae et Sociologica címmel. Fôszerkesztője, Dr. Kiss János köszöntőjében a következôképpen foglalta össze a kiadvány létrehozásának céljait:

„Egy olyan folyóiratot szeretnénk útjára indítani, melynek keretein belül mó- 
dunkban áll megmutatni a karon folyó tudományos munka eredményeit. A címválasztással azt is szeretnénk jelezni, hogy csatlakozunk egy régi felsóoktatási hagyományhoz, s ezzel egy újabb „Acta” kerülhet a tudomány könyvespolcára. Kicsit tematizálva, kicsit konceptualizálva, de mindenképpen egymás mellett bemutatva a karral munkakapcsolatban lévó, de a tudományos kutatómunka különbözó szintjein alkotó szakemberek munkáit. Fontos célunk, hogy publikációs fórumot teremtsünk fiatal kollégáknak, a karunkon múvelt tudományok és határterületeik (egészségtudományok és társadalomtudományok) témáit feldolgozó tanulmányaik számára."

A két folyóirat indítása is jelzi, hogy jelentôsen bôvült a kar tudományos potenciálja, részben annak is köszönhetően, hogy a kar vezetése egy több részból álló, de egységes rendszerré fejlesztett tudománytámogatási stratégiát dolgozott ki. Az elmúlt években több kutatási program is elindult a karon, mind az egészségtudományok, mind a társadalomtudományok területén, néhány esetben pedig interdiszciplináris megközelítésben. Ezek a programok megfelelően illeszkednek a kar képzési profiljához, számos esetben pedig nemzetközi, illetve hazai együttmúködésben valósulnak meg. Az egészségtudományi kutatások esetében a kar legfontosabb partnere az egyetemen belül a Népegészségügyi Kar.

A teljesség igénye nélkül érdemes kiemelni néhány fontosabb, jelenleg is zajló kutatási programot:

A háziorvosok szerepe a méhnyakrákszưrés hatékonyságának növelésében, A várandóság alatti dohányzás hatása az időelőtti és alacsony testsúlyú születésre, Szabolcs-Szatmár -Bereg megyében, A telepszerű körülmények között élő serdülőkorú fiatalok egészsége és életmódja, Egészségi állapot felmérés a telepszerú körülmények között élő észak-keletmagyarországi lakosság körében.

2008 és 2010 között a kar oktatói is résztvevői voltak az ún. EUGATE programnak (European Best Practices in Access, Quality and Appropriateness of Health Services for Immigrants in Europe), amely a bevándorlók számára nyújtott egészségügyi ellátáshoz való hozzáférés legjobb gyakorlatait vizsgálta az unió 16 országában.

Az ápolás és betegellátás alapszak a régióban kifejlesztett, az egészségügyi szakdolgozók helyzetével, illetve a nók egészségügyben betöltött szerepével foglalkozó kutatását az ország többi egészségügyi karának bevonásával végzi, hogy minél inkább összehasonlítható adatokat kapjanak a lakosság egészségi állapotáról, az idősek ellátási lehetôségeirôl. Nemzetközi szinten eddig 5 ország (cseh-lengyel-szlovákszlovén-török) ápoló képzést folytató felsôoktatási intézményeivel folyik a megkezdett kutatás, melynek témája az ápolók helyzete, viszonyítva az Európai Uniós elvárásokhoz, valamint a WHO adataihoz.

Négy ország együttmúködésével, EU támogatással, zajlott a „Toward Active Old Age" kutatási program, melyben a Magyar Ápolási Egyesület felkérésére a kar Ápoló szakja volt a magyar partner. A programot egy sikeres Leonardo da Vinci Pilot Project pályázat támogatta. A kutatási eredmények hazai és külföldi szakmai lapokban kerültek publikálásra.

Az Egészségügyi Informatikai Tanszéken 2 kutatócsoport is múködik, az egyik 
témája a távoktatás, feladata pedig a távoktatás, e-Learning, blended learning fogalmakhoz tartozó tudományterület alapos megismerése, feltárása és a képzésekben történô alkalmazása.

Az Egészségügyi adatfeldolgozó kutató csoport feladata az egészségügyi informatika, az egészségbiztosítás és egészségturizmus területén statisztikai vizsgálatok, elemzések végzése.

A társadalomtudományi kutatások közül kiemelendő a 2008-ban indult Életminôség Nyíregyházán elnevezésú program, amelyet a kar a város önkormányzatával közösen valósít meg. Nyíregyháza Megyei Jogú Város Polgármesteri Hivatal Szociális Osztálya és a Debreceni Egyetem Egészségügyi Kar Alkalmazott Társadalomtudományi Tanszéke 2008-ban indította el azt a városi kutatássorozatot, melynek célja a városlakók életminôségének folyamatos figyelemmel kísérése, a változások elemzése és bemutatása.

A vizsgálat elsố adatfelvételére 2008-ban, a második hullámra 2010-ben került sor. A kutatás nemzetközi és hazai mintákon alapul, mely az ún. háztartáspanel módszertanát követi. Ennek lényege, hogy elsődlegesen a városi háztartásokról gyújt információkat, másodsorban a háztartástagok meghatározott jellemzôirôl.

Sajátossága, hogy azonos lakossági mintán, azonos kérdőívvel próbálja feltárni a változásokat, úgy, hogy a kérdezók ugyanazokat a háztartásokat keresik fel meghatározott időközönként. A vizsgálatban összesen 2000 háztartás vesz részt.

A tanszék munkatársai 2010 óta résztvevői az MTA Politikai Tudományok Intézetével közösen elnyert OTKA kutatásnak, amely a gazdasági válságot, illetve az arra adott válaszreakciókat elemzi nemzetközi összehasonlításban.

Az egyes kutatási programok eredményeit a kar munkatársai számos hazai és nemzetközi konferencián mutatták be, több alkalommal a kar által szervezett tudományos rendezvényeken. Az elmúlt idôszakban ugyanos igen élénkké vált a kar konferenciarendezési aktivitása, a 2006 és 2011 közötti időszakban 15 nemzetközi, 16 országos és számos helyi konferenciának adott otthont az intézmény.

\section{Források}

- A Debreceni Orvostudományi Egyetem Egészségügyi Fôiskolai Kar Jubileumi Évkönyve 1990-1995. (Szerk.: Dr. Karmazsin László, Szedlák Richárd) Nyíregyháza, 1995.

- A Debreceni Egyetem Egészségügyi Fóiskolai Kar Jubileumi Évkönyve 19902000. Nyíregyháza, 2000.

- A Debreceni Egyetem Egészségügyi Fơiskolai Kar Diplomás Ápoló Szak Jubileumi Évkönyve 1993-2003. (Szerk.: Prof. Dr. Kakuk György) Nyíregyháza, 2003 .

- A Debreceni Egyetem Egészségügyi Kar Jubileumi Hírlevele I-III. (Szerk.: Fábián Gergely) Nyíregyháza, 2010. 
- A tizenöt éves Egészségügyi Fôiskola jubileumi évkönyve 2005. (Szerk.: Dr. Lukácskó Zsolt) Nyíregyháza, 2005.

- Fábián Gergely (2010): Húsz év az egészségügyi és szociális képzések szolgálatában. (In: Szabolcs-szatmár-beregi Szemle. 4. 489-497.)

- Góth László: A Klinikai Kémiai Analitikai Tanszék története 1999-2007. Kézirat.

- Öt éves a Gyógytornász Szak - Jubileumi Évkönyv 1999-2004. (Szerk.: Dr. Cseri Julianna) Nyíregyháza, 2004. 
Dr. Fábián Gergely dékán, fóiskolai tanár

Debreceni Egyetem, Egészségügyi Kar, Nyíregyháza, 4400, Sóstói út 2-4. 